


\title{
Developmental Origins of Health Inequality
}

\author{
Gabriella Conti1 ${ }^{1}$, Giacomo Mason², Stavros Poupakis ${ }^{3}$
}

\begin{abstract}
Building on early animal studies, $20^{\text {th }}$-century researchers increasingly explored the fact that early events - ranging from conception to childhood - affect a child's health trajectory in the long-term. By the 21st century, a wide body of research had emerged, incorporating the original 'Fetal Origins Hypothesis' into the 'Developmental Origins of Health and Disease'. Evidence from OECD countries suggests that health inequalities are strongly correlated with many dimensions of socio-economic status, such as educational attainment; and that they tend to increase with age and carry stark intergenerational implications. Different economic theories have been developed to rationalize this evidence, with an overarching comprehensive framework still lacking. Existing models widely rely on human capital theory, which has given rise to separate dynamic models of adult and child health capital, within a production function framework. A large body of empirical evidence has also found support for the developmental origins of inequalities in health. On the one hand, studies exploiting quasi-random exposure to adverse events have shown long-term physical and mental health impacts of exposure to early shocks, including pandemics or maternal illness, famine, malnutrition, stress, vitamin deficiencies, maltreatment, pollution and economic recessions. On the other hand, studies from the 20th century have shown that early interventions of various content and delivery format improve life course health. Further, given that the most socioeconomically disadvantaged groups show the greatest gains, such measures can potentially reduce health inequalities. However, studies of long-term impacts, as well as the mechanisms via which shocks or policies affect health, and the dynamic interaction amongst them, are still lacking. Mapping the complexities of those early event dynamics is an important avenue for future research.
\end{abstract}

Keywords: Developmental origins, health inequalities, early Interventions, health production function, health economics

Acknowledgments. This is a draft of an article that has been commissioned for publication by Oxford University Press as part of the Oxford Research Encyclopedia of Economics and Finance, http://economics.oxfordre.com/ . Gabriella Conti and Stavros Poupakis have received funding from the European Union's Horizon 2020 research and innovation programme (grant agreement No. 633595 DynaHEALTH). Gabriella Conti has also received funding from the European Research Council (ERC) under the European Union's Horizon 2020 research and innovation programme (grant agreement No. 819752).

\footnotetext{
${ }^{1}$ University College London, Institute for Fiscal Studies, and IZA Bonn.

${ }^{2}$ Competition and Markets Authority

${ }^{3}$ University College London
} 


\section{Introduction}

The study of early development started at the end of the $19^{\text {th }}$ century with the German biologist Wilhelm Roux, the founder of a new discipline that he called "developmental mechanics". Roux's experiments with frogs' embryos, and later the experiments by Hans Driesch with sea urchin eggs, were the first studies on the interactions of an embryo with its environment, and how developmental trajectories could be guided by information from its surroundings.

In the first part of the $20^{\text {th }}$ century, infancy and childhood were considered critical phases in determining an individual's lifespan. The actuary Derrick (1927) showed that age-specific mortality rates plotted against year of birth were parallel; he interpreted this finding as indicating that the secular decline in mortality in England and Wales could be better explained as each succeeding generation displaying a lower mortality risk at all ages ("a 'generation' influence", p.144).. The landmark Lancet paper by Kermack et al. (1934) was the first to point to the importance of the early life environment (and of maternal health): "[t]hese results are consistent with the hypothesis that the important factor from the point of view of the health of the individual during his whole life is his environment up to the age of say 15 years, and that improved conditions at later ages have little direct effect" (Kermack et al., 1934, p. 703). However, interest in the early life environment fell after Second World War, when the cohortbased mortality predictions were not fulfilled, since in the 1930s mortality rates for adults stopped declining as a result of higher deaths from heart disease. Kuh and Davey Smith (1993) describe how the 'generational approach' to forecasting mortality was rejected by the Statistics Committee of the Royal Commission on Population in the early 1950s.

After a few decades, the idea of early life influences on health gained momentum once more in the 1970s. In 1973, Forsdahl (1973) - reprinted as Forsdahl (2002) - analysed Norwegian data and posited an association between poor living conditions in childhood and adolescence and adult mortality. Forsdahl (1973)'s analyses were the first of a series of epidemiological association studies which investigated the long-term effects of early conditions, and which had David Barker as one of the most visible supporters. In a first paper, Barker and Osmond (1986) found a large positive correlation between standardised infant mortality rates in 1921-1925 and mortality among adults for ischaemic heart disease in 19681978. Subsequently, Barker and Osmond (1987) used maternal mortality in 1911-1914 as an indicator of the early environment, and found a strong correlation with death rates from stroke for the generation born at that time. Barker et al. (1989a) is considered the first paper which gave rise to the "Fetal Origins Hypothesis". The authors showed that the mortality rates from stroke in local authorities in England for the years 1968-1978 were more closely related to neonatal than postneonatal mortality during 1911-1925, emphasizing the importance of the uterine (rather than postnatal) environment. In a series of papers based on the Hertfordshire Cohort Study, starting with Barker et al. (1989b), they showed that men with the lowest weights at birth and at age one had the highest death rates from ischaemic heart disease. Subsequently, the Fetal Origins Hypothesis evolved into the "Developmental Origins of Health and Disease" (DOHaD, Gluckman and Hanson (2006)), to recognise the fact that the influence of the early life environment started at conception and extended well into childhood.

Building on the epidemiology tradition, economics in the last years has seen a burgeoning of research investigating the long-term effects of early conditions, and two main surveys of 
the literature have been already carried out (Currie and Almond, 2011; Almond et al., 2017). Economists have provided important contributions to the field: they range from developing theoretical frameworks, to establishing causality, understanding mechanisms, and also computing costs and benefits of early interventions. Due to space constraints, this chapter is limited to reviewing the evidence on the long-term health impacts of early events in developed countries. To understand the scope of this review, it might be useful to consider the type of studies that are are not included. First, studies which only look at short-term outcomes, such as health at birth or in childhood, are omitted. Secondly, the review excludes studies that examine exclusively economic outcomes such as employment and earnings; in cases both health and human capital outcomes are studies in one paper, it will focus on the former. Third, studies on the impacts of shocks and investments occurring in adulthood are not reviewed. Throughout, the contents largely rely on published work. The fact that, even within these limits, the reviewed body of work is substantial, testifies to the tremendous interest generated by this field in the early $21^{\text {st }}$ century, which is why this review also includes some particularly relevant working papers from that time.

This chapter is organised as follows. The next section presents a brief overview of the historical evolution of inequalities in health. It is followed by a review of the pertinent theoretical frameworks. Afterwards, the economic evidence on the long-term health effects of early shocks, policies, and their interactions will be examined. Finally, the conclusion discusses unanswered questions and future research directions. A set of Appendix tables contains key features of each paper in more detail.

\section{Evidence of Health Inequalities}

Income inequality has been rising steadily in OECD countries. Evidence from the years 2015 and 2016 shows those at the top of the income distribution becoming even wealthier, at the expense of a shrinking middle class (Lakner and Milanovic, 2016). Inequality in life expectancy and mortality has increased over the past 20 years in the United States among the older aged population (Chetty et al., 2016; Case and Deaton, 2015). Other evidence shows that mortality gaps between those most well-off and those least well-off are actually decreasing in individuals of younger age (Currie and Schwandt, 2016).

Enduring health inequalities are related to educational attainment. For example, education gradients in mortality appear to be increasing both in the United States (Pappas et al., 1993) and Europe (Mackenbach et al., 2003; Kunst et al., 2004). In the U.S., decreasing disability rates are, in fact, mainly experienced by the most educated Schoeni et al. (2008). In essence, each additional year of schooling correlates with better health (Lleras-Muney, 2005), although there is no clear evidence of a causal relationship (Galama et al., 2018).

Socio-economic status (SES) relates to health in multiple ways. First, higher SES children enjoy a healthier and more nurturing environment since the prenatal period. For example, low-SES mothers tend to behave detrimentally to their fetus in a way that mothers from higher SES do not - such as smoking and drinking during pregnancy (Currie and Moretti, 2003; McCrary and Royer, 2011), or gaining excessive pregnancy weight (Ludwig et al., 2013a). Second, low-SES children are both more likely to develop health conditions, and less able to recover from them (Condliffe and Link, 2008). The effect of SES is then prolonged, as more unhealthy children from poor mothers may not be able to compensate the accumulated 
disadvantage. Hence, initial disparities between low and high SES groups increase over the life cycle (Case et al., 2002), although they tend to narrow at older ages (Case and Deaton, 2005). ${ }^{4}$ This "long reach" of childhood socioeconomic disadvantage is documented in various contexts. Figure 1 shows average life-cycle profiles of BMI for individuals born into different cohorts in the UK, separately by parental social class at birth. All cohorts exhibit widening gaps between high- and low- social class children well into adulthood, with gaps emerging earlier and becoming more pronounced for later cohorts. Further work which has decomposed the sources of adult health inequality by education has shown that a substantial part of the gradient can be explained by child development and the family environment in the first ten years of life (Conti et al., 2010).

Health inequalities also have stark intergenerational implications. Not only do children from disadvantaged backgrounds carry on their health conditions into adulthood, but also it becomes apparent that their own children face increased health risks. For example, Currie and Moretti (2007) find children of mothers born with low birth weight to have a $50 \%$ higher likelihood of being born with low birth weight themselves. This effect is particularly strong in high-poverty areas. Moreover, evidence from the US shows that intergenerational health mobility is much greater than income mobility, with important heterogeneities across gender, race, education and location (Halliday et al., 2018).

\section{Theory}

This section provides a brief overview of economic theoretical approaches that can rationalise the mounting empirical evidence on the developmental origins of adult health. Most of these approaches are rooted in human capital theory. Human capital can be defined as the intangible stock of knowledge, skills, personality, and other attributes - including health - that produce economic value in the life of an individual.

Human capital theory, pioneered in the 1960s (Becker, 1962, 1964, 1965, Ben-Porath, 1967), has long been employed as a guiding economic framework for understanding individual decisions across the life course. Human capital theory considers the individual (or the household) as a productive unit, which employs market goods and services in conjunction with its own time and transforms them into commodities that generate utility. ${ }^{5}$

Stemming from this literature, the seminal work by Michael Grossman (1972a,b, 2000) recognised the peculiarity of health among the dimensions of human capital. The model revolves around the concept of health capital: at any point in time, individuals are endowed with health, that provides direct utility but - unlike the commodities in Becker's approach - is a stock. Health depreciates through time due to the ageing process, but can be replenished by health investments (traditionally, medical care). In the remainder of this section, this and the related frameworks are referred as the adult health capital approach. ${ }^{6}$

\footnotetext{
4 The narrowing might in part be a consequence of selective mortality or culling effects.

${ }_{5}$ As an example, groceries and time spent cooking can be used to produce meals, or a bike and time spent pedalling can produce physical activity.

${ }^{6}$ For more in depth treatment of the health capital approach and detailed surveys of its theoretical extensions and empirical applications, see among others Grossman (2000) and Gilleskie (2008).
} 


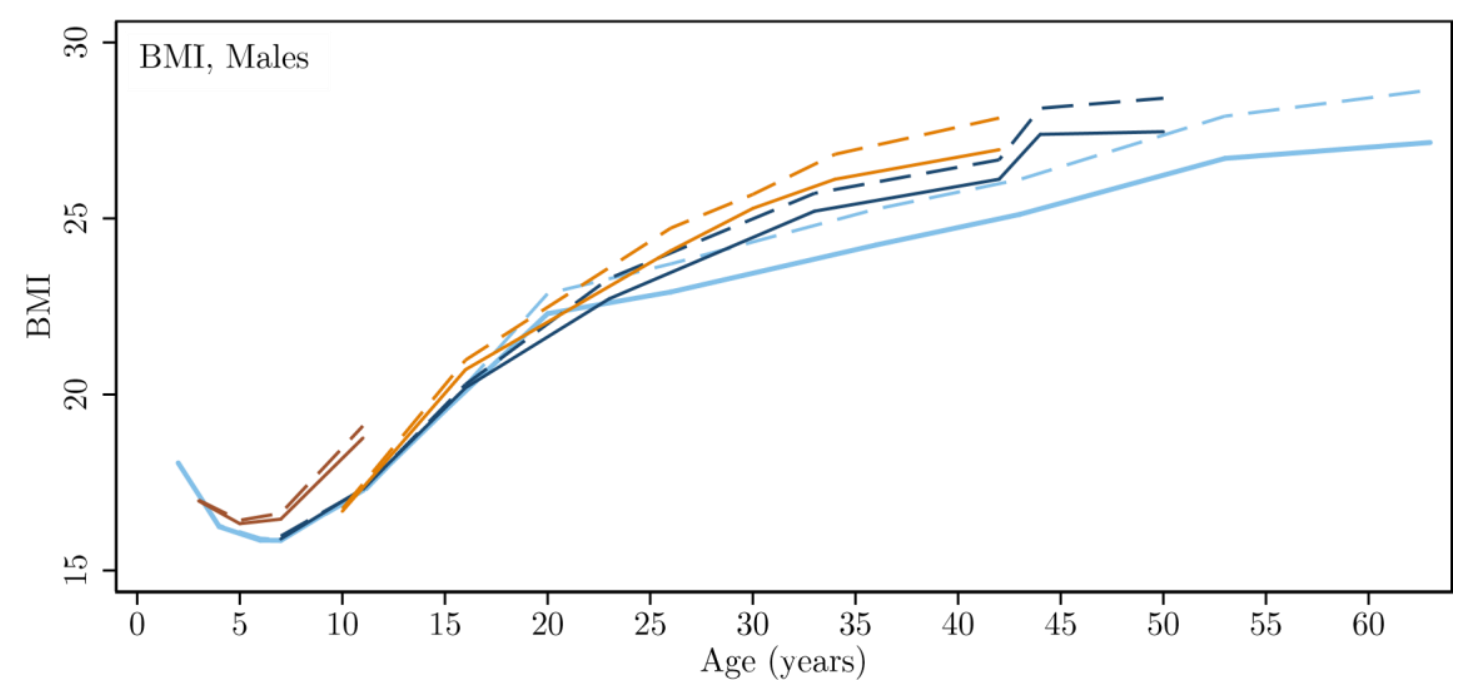

Figure I(a)

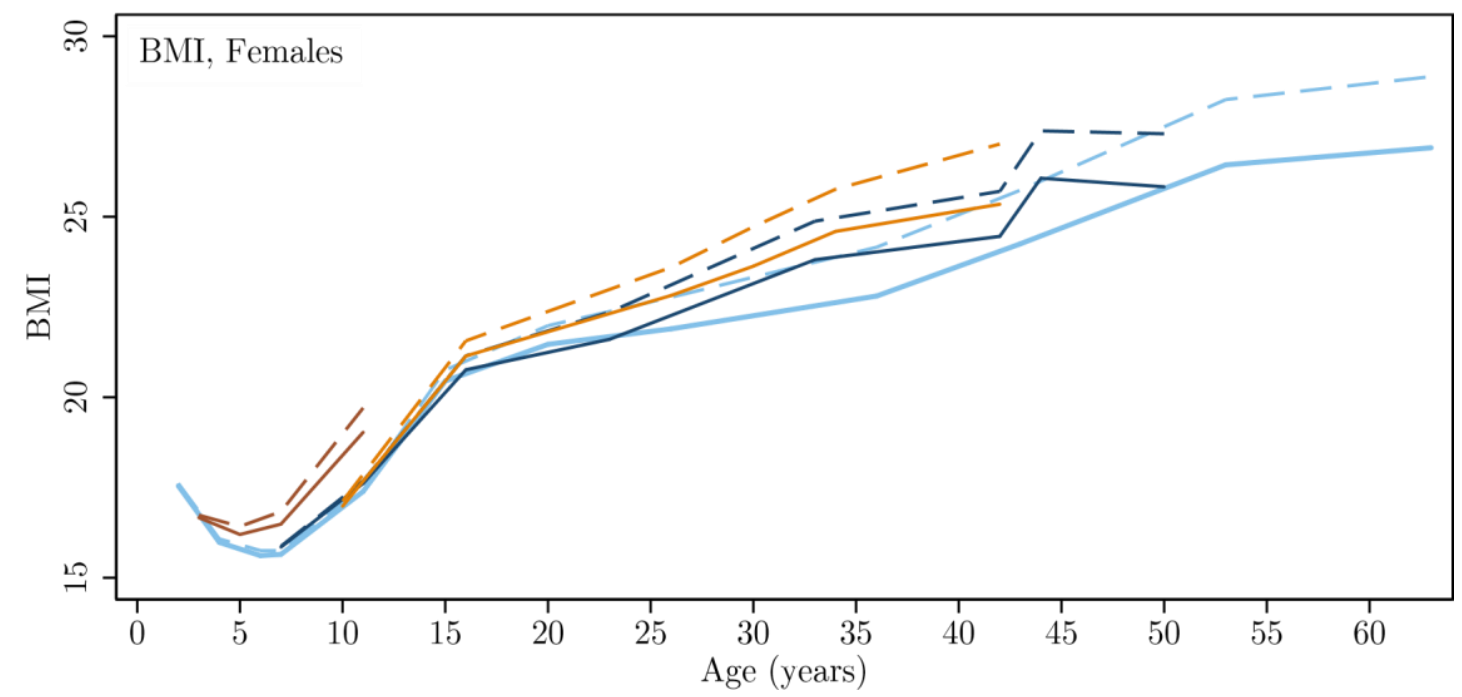

Figure $I(b)$

FIGURE I (a,b): Mean BMI Age Profiles By Gender (Males, Females)

$\begin{array}{rlll}\text { NSHD (1946) } & \text { High SES } & \text { Low SES } & - \\ \text { NCDS (1958) } & \text { High SES } & \text { Low SES } & - \\ \text { BCS (1970) } & \text { High SES } & - \\ \text { MCS (2000/1) } & \text { High SES } & \text { Low SES } & - \\ \text { Migh } & \text { Low SES } & - \\ \end{array}$

Sources: The figure shows mean BMI age profiles by gender, for four birth cohort studies in the UK: the National Survey of Health and Development (NSHD), the National Child Development Study (NCDS), the British Cohort Study 1970 (BCS), and the Millennium Cohort Study.

Notes: Socioeconomic status is based on a dichotomisation of parental occupational social class at birth, according to the Registrar General's 1990 classification. High SES corresponds to classes I (Professional), II (Managerial), IIINM (Skilled non-manual). Low SES corresponds to IIIM (Skilled manual), IV (Partly skilled), V (Unskilled). Children whose parents are in the armed forces, carer unemployed, long-term sick, or retired are excluded. Observations for which social class was coded as unclassifiable, or insufficient information was available in the data are also excluded. For BCS and NCDS, the indicator is based exclusively on the father's occupation. For MCS, the indicator is based on the highest between father's and mother's occupational social class. Both the BMI and social class data are harmonised across cohorts, as part of the CLOSER initiative (closer.ac.uk). 
In keeping with the human capital approach, the process of transformation of investments into additional health stock is conceptualised as a health production function. In its simplest form - adapted from Grossman (2000):

$$
H_{t+1}=\left(1-\delta_{t}\right) H_{t}+I\left(M_{t}, T_{t} ; E\right),
$$

where $H$ is the health stock, $\delta$ is the deterioration rate of health, and $I(\cdot)$ is health investment as a function of medical care $M$ and time spent on medical care T. Basically, individuals are viewed as producers of their own health: they cannot augment their health stock directly, but they invest $M_{t}$ and $T_{t}$ out of their available monetary and time resources in each period to offset the deterioration of their health capital. The production process is also influenced by the individual's education $E$, which is assumed to improve productivity. An individual's health capital stock in turn influences her utility directly (consumption motive) and/or her labour market productivity and income (investment motive). Thus, the demand for medical care is only derived from the demand of health, which has utility and income consequences. Here, health investment is viewed primarily as curative care. An important aspect of this basic formulation is linearity: the beginning-of-period health stock enters separately from the investment function, thus assuming that effectiveness of investment is the same at all levels of initial health.

By explicitly recognising the dynamic nature of health, Grossman's health capital model has since become the "workhorse" model in health economics. It has been used as the reference framework for understanding the evolution of individual health during adulthood and late life, and has spurred a vast legacy of related literature and theoretical extensions. ${ }^{7}$ However, it has also attracted substantial criticism due to a number of apparent shortcomings, both in its theoretical implications and its ability to replicate empirical patterns. ${ }^{8}$ Subsequent work has sought to address such flaws by equipping the standard Grossman model to explain a wider range of empirical phenomena. Galama (2015) shows that assuming decreasing returns to scale (DRTS) in the health production process and correctly interpreting equilibrium conditions derived from the health capital model can address much of the criticisms levied in the past from the theoretical side. Furthermore, Galama and Van Kippersluis (2015) propose an extended Grossman-type model that, thanks to a number of additional features, is able to replicate salient features of adult health trajectories - such as the persistence of socioeconomic

\footnotetext{
${ }^{7}$ For example, Muurinen (1982) has a generalised version with both consumption and investment motives; Cropper (1977) and Dardanoni and Wagstaff $(1987,1990)$ study the implications of introducing uncertainty in the model. 8 Firstly, Ehrlich and Chuma (1990) claim that the constant returns to scale (CRTS) shape of the investment function adopted by Grossman generates a so-called 'bang-bang' equilibrium, where individuals can immediately adjust their health capital stock to the optimal level; furthermore, due to the same CRTS assumption, individuals would be able to choose to live for an infinite amount of time (Case and Deaton, 2005). Secondly, it has been noted that model solutions are somewhat 'memoryless', in that the optimal choice of health investment does not depend on the histories of health investment and ageing (Wagstaff, 1993). Finally, the model has been shown to predict - at least in its most basic formulation - a positive association between health status and health expenditure in the cross section. This feature is inconsistent with empirical evidence showing that healthier people exhibit lower health expenditure (Zweifel and Breyer, 1997).
} 
health disparities across the life course, and in particular the initial widening of SES gradients and their subsequent shrinking around retirement. ${ }^{9}$

The Grossman approach is mostly focused on adulthood and older age. It is very plausible that the nature of the human capital production process is very different in earlier stages of life; this seems to be true both in terms of the relevant dimensions of human capital involved, and which forms of investments are effective in their accumulation. In the past decade or so, renewed attention has been devoted to understanding the process of human capital development in early life, encompassing the period from conception to late childhood. This increasingly popular strand of literature will be henceforth referred to as child human capital approach.

In accordance with human capital theory, the process of development in children is also modelled via a production function (Heckman, 2007):

$$
\theta_{t+1}=f_{t}\left(\theta_{t}, I_{t}, \theta_{t}^{B}, \varepsilon_{t}\right)
$$

where $\theta_{t}$ represents child human capital, $I_{t}$ are investments, $\theta_{t}{ }^{B}$ summarises background/environment factors, and $\varepsilon_{t}$ are independent random shocks. ${ }^{10}$

The theoretical constructs of human capital and investments in this framework are different from the adult human capital approach. It has long been recognised that many aspects of children's development have important consequences across the life course. Cognitive ability has historically been the main focus, with a large body of work examining its determinants in the early years (Todd and Wolpin, 2003). At the same time, a separate literature studies physical development - often proxied by height and BMI (Mandal and Powell, 2014; Puentes et al., 2016). Finally, research in the early $21^{\text {st }}$ century has seen an increased focus on socioemotional skills (Carneiro et al., 2007). An important feature is that child human capital $\left(\theta_{t}\right)$ is recognised as a multidimensional object, with health, cognitive ability, socioemotional skills, and personality traits among the various dimensions. At the same time, investments also reflect this multidimensionality, ranging from healthy behaviours (smoking in pregnancy, breastfeeding) to time and money spent in stimulating activities. ${ }^{11}$

The very general formulation of (2) allows for a rich characterisation of the development process, if a suitably flexible empirical specification - e.g. a CES - is chosen. Salient properties

\footnotetext{
${ }^{9}$ The additional features that are absent in the standard Grossman approach are (mainly): the explicit modelling of labour market returns and unhealthy labour; a shift from a narrow focus on medical care inputs to a wider range of healthy and unhealthy consumption, and an endogenous retirement decision. While this is the first time these features are integrated together in a Grossman-like model, investigation of such aspects is not completely novel see for example Becker and Murphy, 1988; Kenkel, 2000 for unhealthy behaviours, House et al., 1994; Marmot et al., 1997 for unhealthy work environments, and French, 2005 for health and retirement decisions.

${ }^{10}$ Notice that the Grossman formulation of the health production function in (1) can be viewed as a special case of (2).

11 Both human capital and investments are often operationalised as latent variables, using factor-analytic techniques to infer the dimensionality of the latent constructs and extract information from error-ridden measures - see for example Cunha et al. (2010) or Conti et al. (2014).
} 
include self-productivity $\left(\frac{\partial \theta_{t+1}}{\partial \theta_{t}}>0\right)$ and dynamic complementarity $\left(\frac{\partial^{2} \theta_{t+1}}{\partial \theta_{t} \partial I_{t}}>0\right), \quad$ whereby current levels of human capital affect both future levels and the productivity of current investment (Cunha and Heckman, 2007). ${ }^{12}$

Furthermore, this approach recognises and emphasises the role of shocks (see the following section). The extent to which a shock $\varepsilon_{t}$ in period $t$ affects human capital in the long term not only depends on the 'biological' effect of the shock on the development process, but also on any investment reaction. Flexible formulations of (2) can inform about whether parental investments act to reinforce or compensate earlier shocks (Currie and Almond, 2011).

Both the adult and child human capital approaches have proven capable of generating consistent predictions that find confirmation in empirical analysis. They build on the same basis - the human capital model - which arguably suggests that a unified theory is possible. However, a framework that synthesises the two approaches and encompasses the whole life cycle is still fundamentally lacking.

The childhood and adulthood periods have so far been treated and modelled separately. This is perhaps due to the inherent complexity in modelling human capital investment decisions along the life course. Starting from childhood, decisions are made by the parents. Through the secondary and higher education periods, the individual herself becomes the decision maker: adult labour market and health outcomes are determined by the interaction of the human capital stock accumulated during childhood with schooling, labour supply, fertility, and other choices. Existing approaches to model the entire life cycle have required dynastic or overlapping-generation models (Halliday et al., 2016; Gayle et al., 2017). Furthermore, as previously mentioned, the evolution of health has been studied somewhat separately from the other dimensions of human development - a limitation which only work produced after the turn of the millennium has started to overcome (Becker, 2007).

While human capital is the predominant theoretical approach in this field, other paradigms are available. For example, a theory of ageing based on the accumulation of health deficits has been advanced by Dalgaard and Strulik (2014). They draw on insights from the medical literature on ageing, and propose that individuals are characterised by a stock of health deficits $D_{t}$, which evolve through time in a fashion similar to health capital in the Grossman model:

$$
D_{t}-D_{t-1}=\mu\left(D_{t-1}-E\right)
$$

where $\mu$ is the "natural" rate of ageing and $E$ are environmental influences, including deliberate investments such as health behaviours and curative care.

This model generates radically different predictions from the human capital model regarding developmental origins of adult health. The assumption that depreciation is proportional to human capital stock, which underlies the human capital model, means that the effect of early disparities are dampened through time. There is still a possibility that such

12 Notice that when human capital and investment are multidimensional, cross-productivities and crosscomplementarities are also possible. For example, better health can increase the effectiveness of investments in cognitive skills; different investments - e.g. nutrition and psychosocial stimulation, or schooling in different periods - are allowed to exhibit an arbitrary degree of contemporaneous and intertemporal substitutability. Note that investments can include early childhood interventions, as described in section 5 . 
disparities are persistent, but only via their effect on investments $I_{t}$. In the health deficits framework, instead, individuals who are initially less healthy have a faster accumulation of health deficits, allowing for persistent - or widening - disparities in later life. Dalgaard et al. (2017) argue that such features make the health deficits approach more suitable for modelling developmental origins of health.

\section{Shocks}

As highlighted in the previous section, contributions in human capital theory have increasingly explicitly incorporated the role of shocks in the process of human development. Indeed, a substantial number of studies has documented the long reach of early shocks, exploiting quasi-random exposure to adverse events of various nature. In this section, they will be briefly reviewed by type of shock broadly defined.

One of the first studies in economics to provide long-term evidence for the 'fetal origins hypothesis' investigates the effect of in utero exposure to the 1918 influenza pandemic in the US, and finds that the exposed cohort was more likely to suffer from physical disability in late adulthood (Almond, 2006). In a related contribution, Almond and Mazumder (2005) document a higher likelihood of reporting poor health, a range of functional limitations (hearing, speaking, lifting, and walking), and diabetes or stroke for the affected cohort.13. A contribution by Fletcher (2018), instead, suggests no effect of the influenza epidemic on overall mortality or death by specific causes. Turning to Europe, Bengtsson and Helgertz (2015) find significant effects on hospitalisations and mortality from prenatal exposure to the flu in Sweden. While the hospitalisation effect varies by gender and time of exposure (for boys is concentrated in the second trimester, for girls in the third), the mortality effect is found only for boys. ${ }^{14}$

Another widely investigated event is exposure to famine, as source of quasi-random variation in prenatal nutritional intake. In the theoretical framework of section 3 , this can be conceptualised as a shock to maternal prenatal investments. A commonly exploited historical setting in the literature is the rationing of food supply which occurred at the time of World War II. Large effects of famine exposure are found in the Netherlands on the likelihood of hospitalisation (Scholte et al., 2015) and on height (Portrait et al., 2017; Van den Berg et al., 2016, the latter including also Germany and Greece), and in Germany on obesity and metabolic syndromes (Kesternich et al., 2015). Furthermore, similar effects have been estimated for adult mortality for the Dutch Potato famine, which occurred a century before WWII (Lindeboom et al., 2010). In all these studies, men appear more affected by famines than women, consistently with the idea that male fetuses are more vulnerable than female fetuses. Moreover, families living in urban areas appear more affected than those living in rural areas, and especially farmers who could rely on home production to protect themselves against food shortages. However, famine studies have been criticised, on the grounds that those particular circumstances must have also caused severe stress (and when occurring during a war, loss of

\footnotetext{
13 Brown and Thomas (2016) raised selection concerns about the original analysis, but (Beach et al., 2018) have shown that they are unfounded, and have confirmed the original results

14 For a systematic review of studies looking at the 1918 influenza pandemic around the world, see Vollmer and Wójcik (2017).
} 
material resources), making it difficult to separately identify the effect of undernutrition. Indeed, studies which have examined more broadly the impact of experiencing a war in early life (B" orsch-Supan and Ju"rges, 2011; Kesternich et al., 2014; Schiman et al., 2017; AkbulutYuksel, 2017; Havari and Peracchi, 2017) have also found similar adverse long-term consequences. ${ }^{15}$ Nonetheless, the negative impacts of wars appear to affect to the same extent both men and women, and individuals belonging to different socioeconomic strata.

Researchers have devised alternative identification strategies to study the effects of prenatal malnutrition, such as exposure to Ramadan for children born to Muslim women. Almond and Mazumder (2011) use variation in the day's duration during Ramadan observance in a US state (Michigan) and two developing countries (Uganda and Iraq) to identify the reduced-form effect of prenatal Ramadan exposure. They find evidence of significant effects on birth weight (for Michigan) and adult disability of any kind (for Uganda and Iraq), with the strongest effects observed on mental disability.

Another popular strategy to study prenatal nutrition exploits within-twin pairs birth weight differences, determined by random variation in nutrients intake due to different positioning of the twin fetuses in the womb. A first important finding from this strand of work is the strong intergenerational persistence of birth weight (Black et al., 2007; Royer, 2009). Second, the evidence emerging from these studies on the role of birth weight in determining long-term health is mixed. For example, Behrman and Rosenzweig (2004) find effect of birth weight on adult height but not on obesity using U.S. data, while Black et al. (2007) find that an increase in birth weight is associated with an increase in BMI and height using data from Norway. Moreover, they find substantial distributional effects: for example, the positive association with height only exists for birth weights up to $1.5 \mathrm{~kg}$. Using twin birth data from California, Royer (2009) finds an effect of birth weight on adult health outcomes (such as hypertension) only below the low birth weight threshold. In a contribution based on Swedish data, Bharadwaj et al. (2018) find that birth weight has a significant and economically meaningful impact on sickness benefits take-up, hospitalisations, and mortality (the latter only for males). Lastly, Wernerfelt et al. (2017) study the effects of vitamin D deficiency, common among pregnant women, by exploiting variation in sunlight by county together with time use data in a US sample. They find that children whose mothers had an increased sunlight exposure, particularly during the second trimester, had a reduced likelihood of developing asthma. ${ }^{16}$

In addition to nutrition, maternal stress can be viewed as another input in the production of fetal health. Persson and Rossin-Slater (2018a) use the timing of death of a mother's family member around birth - whether it occurred in utero or postnatally. Families in both groups are equally likely to be affected by the death of the relative and its consequences, with the only difference being in the timing. They are thus able to distinguish the biological transmission of stress from environmental (e.g. income) effects. They find that prenatal exposure to stress is

\footnotetext{
15 Although some of these studies rely on retrospective assessments, it has been shown that older people's recall of childhood events are trustworthy. For example, Havari and Mazzonna (2015) using survey data from Europe show that respondents' recall data are consistent with external aggregate data such as GDP per capita, schooling and war episodes.

16 The importance of nutrition for health and prosperity plays a central role in the work of Fogel, see for example Fogel (1997).
} 
negatively linked to mental health later in life, and equally affects mothers of all education levels - an important result given the strong intergenerational persistence of mental health (Johnston et al., 2013). ${ }^{17}$

Since the seminal contribution of Bowlby (1969), the lack of a secure attachment relationship is a form of early shock that has been widely studied in the biomedical literature. The few existing papers in the economics literature show that child maltreatment has significant adverse long-term consequences, especially for mental health (see for example Conti et al. (2017); Fletcher (2009)), however, as noted in Doyle Jr and Aizer (2018), more research is needed on the health effects of child abuse and neglect. 18

Environmental shocks due to exposure to various sources of pollution have also received increasingly scrutiny. One strand of the literature has studied the long-term impacts of exposure to radioactive fallout. The first studies have exploited the 1986 Chernobyl accident, and found that the Ukrainian cohorts exposed in utero are more likely to be in poor health and to suffer from anaemia or gastrointestinal illness 20 years later (Lehmann and Wadsworth, 2011). They also have a higher likelihood of mental disorders and reduced expected survival (Danzer and Danzer, 2016). ${ }^{19}$ Following work (Black et al., 2017) has found that radioactive fallout at much lower dosages has a negative impact on cognitive ability (as proxied by IQ tests and education), concentrated among those exposed in the second trimester of pregnancy, but not on physical development. ${ }^{20}$ Little is known, instead, about the long-term health impacts of air pollution from particulates, since most studies focus on education or earnings, or on short-term health effects. ${ }^{21}$ One exception is Bharadwaj et al. (2016), who study the effects of prenatal and early-life exposure to the 1952 Great Smog of London on the lifelong development of asthma. While they find a significant effect in childhood asthma prevalence for those being exposed in the first year of life, the effect in adulthood is not significant.

Lastly, a budding literature has studied the long-term consequences of growing up in recessions. Common findings are negative health effects persisting into late adulthood - see Cutler et al. (2007) in the US, Van den Berg et al. (2006); Scholte et al. (2017) in the Netherlands, and Banerjee et al. (2010) for France.

A potential limitation of the majority of the studies in this section is that they rely on comparisons between exposed and unexposed cohorts to extreme events, which may make the estimated impacts biased due to selection effects. While the effect of interest is that of prenatal 'programming' - in other words, the adverse effect of shocks in utero that children carry over their lives (scarring) - the exposure to such events can have an immediate effect on prenatal mortality for the most vulnerable. This means that the children who survive are the most physically strong and have better outcomes (survival, or culling, effect). ${ }^{22}$ In dealing with

\footnotetext{
17 In response to a comment by Matsumoto (2018), Persson and Rossin-Slater (2018b) show that their results are robust to redefining the control group using the expected rather than actual date of birth.

18 A related study by Santavirta and Santavirta (2014) examines the effect of being placed in foster care in Sweden on children evacuated from Finland at the time of World War II finds no effect of such a change in the family environment on adult depression.

19 Negative health effects are also found by Yemelyanau et al. (2012) for Belarus.

20 Similar effects - on education but not on child health - have been found by Almond et al. (2009) using exposure to the Chernobyl radioactive fallout in Sweden.

${ }^{21}$ For a detailed review on effects of early-life exposure to pollution, see Currie et al. (2014).

22 See Bozzoli et al. (2009) for a didactic discussion of scarring and culling effects.
} 
the selection problem, most of these studies examine selective mortality by looking at the gender ratio at birth, motivated by the biological theory according to which male fetuses have less chances to survive than females, whether due to vulnerability unfavouring males or natural selection in favour of females (Trivers and Willard, 1973).

Lastly, while a consolidated body of evidence shows that early shocks have long-term consequences, little is known about the underlying mechanisms, and particularly about the relative importance of biological pathways versus behavioural responses. ${ }^{23}$ Answering this question requires moving away from reduced-form analysis to estimate more structural relationships. One of the few exceptions is Yi et al. (2015), who study how an early health shock affects adolescent human capital. The authors estimate a linear production function using twins data from China, and show that parents make compensatory investments in health and reinforcing investments in education, hence acting as net equalisers. Although biological effects outweigh the intrahousehold allocation effect, so that the reduced-form estimate substantially underestimates the full impact of a shock in case of compensatory responses, their results also show that some remediation is possible. More work along these lines would be particularly welcome, to understand how different early shocks might be operating in determining subsequent health.

\section{Policies}

As shown in the previous section, children are highly sensitive to adverse circumstances in early life. At the same time, pregnancy and early childhood are viewed as a critical window of opportunity for interventions that promote development. This section reviews evidence on the long-term health effects of a range of early interventions. Notably, only a subset of them refers to the provision of health insurance/health care: the vast majority focus on the so-called social determinants of health, whose importance has been increasingly recognised (see for example Marmot (2005)).

Within each type of policy, a useful distinction is between targeted and universal programmes. Targeted programmes, like income supplementation, usually are delivered to the neediest, so they are designed to help reduce inequalities. For universal programmes, the result is not so clear: needier families might be less capable to fully reap the benefits of a programme, potentially leading to an increase in inequality. This can be contextualised in the theoretical approach presented in the previous section: different public investments might exhibit different degrees of complementarity with initial endowments and private investments. Whether the overall effect reduces or promotes inequality hinges on the direction of these complementarities.

Provision of child care has become increasingly salient in the policy debate, given that most children are placed in some form of care during their pre-school period. Campbell et al. (2014) is the first study to show long-term health effects of an early intervention programme (the Abecedarian) providing stimulation, nutrition and health care to disadvantaged children in the first five years of life. The authors find that the children randomised to the treatment group exhibit a lower prevalence of risk factors for cardiovascular and metabolic conditions (such as hypertension) in their mid-thirties. Along the same lines, using variation in municipalities'

${ }^{23}$ See Almond and Mazumder (2013) for an excellent review on parental responses. 
time of implementation of child care in Denmark, Rossin-Slater and Wu"st (2016) show that access to a high-quality preschool targeted to poor children has persistent effects on health outcomes through age 65. However, in many countries the diffusion of targeted child care programmes has only been widely implemented with the beginning of the $21^{\text {st }}$ century, so that studies of long-term impacts are still unavailable. Nonetheless, medium-term improvements in several health measures have been found for Head Start, a largescale programme targeting disadvantaged children in the US (Ludwig and Miller, 2007; Carneiro and Ginja, 2014). Turning to universal preschool, a contribution by Herbst (2017) (which exploits random variation in preschool implementation in the U.S. during WWII) finds a decrease in workrelated disability by middle age.

Home-visiting programmes are being increasingly advocated as a promising tool to alleviate health inequalities, although there is a limited number of studies investigating their sustained effectiveness. The longest-term evidence available comes from public programmes implemented in the Scandinavian countries at the inception of the welfare state. Hjort et al. (2017) find that a universal home visiting programme in Denmark reduced mortality at ages 45-57, and the incidence of cardiovascular diseases and hospital admissions. Bhalotra et al. (2017) examine an early intervention in Sweden, providing information and support to mothers via home visits and clinics, with an emphasis on nutrition and sanitation. They find similar positive effects in terms of reduced mortality by age 50 and increased survival to age 75 , especially due to reductions in cancer and cardiovascular mortality. While the authors find no differential effects by gender, they document greater gains for the most vulnerable groups (children outside marriage and children of younger mothers), thus pointing to the potential of reducing health inequalities. In the US, despite a plethora of studies looking at the effects of various home visiting programmes, ${ }^{24}$ there has been no study yet showing long-term effects on adult health, as the exposed cohorts are still too young.

Another important set of policies targeting the immediate postnatal period is family leave policies. As noticed in a review by Datta and Gupta (2018), most of the evidence points to weak or zero effects on children's medium-term outcomes, especially when the counterfactual is high-quality care. Only scant evidence, instead, exists on children's long-term health and physical development; this is an important avenue to pursue in future research.

Another line of research focuses on the long-term effects of early childhood access to medical care: a critical input, since early health problems are significant predictors of later health (Currie et al., 2010). Most research exploits the implementation (1960-70s) or the expansion (1980-90s) of Medicaid in the US, a federal- and state-funded programme helping disadvantaged families with children cover medical expenditures. The programme has been found to lead to a reduction in health limitations and chronic conditions at ages 18-21 (Thompson, 2017), mortality at age 28 (Brown et al., 2015), and mortality and disability in the 40s (Goodman-Bacon, 2016). Overall, access to Medicaid is found to be beneficial to participants' long-term health. In relation to the timing of exposure, Miller and Wherry (2018) have shown that those exposed in utero have larger health improvements in their mid 20s than those who were exposed postnatally. This result is corroborated by Boudreaux et al. (2016), who also show that health gains are largest among those exposed to Medicaid during the

24 See Sama-Miller et al. (2016) for a review of the home visiting research literature. 
prenatal period. Furthermore, exploiting a discontinuity around a birthday cut-off, Wherry et al. (2018) find that longer childhood eligibility translates into fewer hospitalisations and reduced disease-related mortality at ages 15-18 (Wherry and Meyer, 2016). The effects are mostly limited to black cohorts, with whites having either smaller or no gains. This heterogeneity underpins the importance of health care in childhood on reducing health inequalities by race over the life cycle.

Complementary evidence from the UK shows that early life medical coverage due to the introduction of the National Health Service (NHS) in 1948 resulted in better health and fewer hospitalisations later in life, especially for women and children of lower social class (Lu“hrmann and Wilson, 2017). Finally, long-term evidence comes from Norway, where Bu"tikofer et al. (2015) exploit the variation across municipalities in the implementation of child health care centres during the 1930s. This universal intervention was aimed at providing information on infant nutrition, and in general to promote child well-being. The authors find that the programme reduced the incidence of diabetes, hypertension and heart attacks at age 40; and was also found to increase overall adult height. ${ }^{25}$

Another strand of work has evaluated specific public health policies, such as universal vaccination. Evidence from Norway, using cohort and regional variation, shows that the 1948 tuberculosis testing and vaccination campaign significantly reduced mortality before the age of 66 (Bu"tikofer and Salvanes, 2018). Gains were higher for those from low socio-economic background, showing again the potential for early childhood interventions to reduce adult health inequalities. Additionally, given that the intervention was administered by the school system, this suggests a potential mechanism behind the widely documented positive effect of schooling on health for early 20th century cohorts (Mazumder, 2007). In related work, Bhalotra and Venkataramani (2015) exploit the introduction of antibiotic therapies in 1937 in the US to examine the effects of infant pneumonia on adult outcomes. Although there were large significant effects on all outcomes studied (among which disability) African-Americans living in more racially segregated states gained less from the programme, compared to those in less segregated states. This suggests the importance of institutions in delivering such programmes to the most disadvantaged, and as a consequence, in tackling health inequality. Finally, improvements in sanitation have been shown one of the most important and successful interventions delivered in the twentieth century in developed countries, especially in larger cities, due to rapid economic growth and urbanisation. For example, Kesztenbaum and Rosenthal (2017) show how the expansion of Paris' sewage system led to an increase in Parisians' life expectancy by several years. Along the same lines, Cutler and Miller (2005) show how access to clean water decreased mortality rates in the US, with greater benefits in cities with higher illiteracy rates. However, Anderson et al. (2018) have challenged these findings, showing that none of the several public interventions studied contributed substantially to reductions in mortality. Importantly, Alsan and Goldin (2015) show that the introduction of drinking water and sewerage systems are complementary interventions, displaying higher effectiveness in decreasing infant mortality when combined. While such public health interventions are established in developed countries, disadvantaged families might still face

25 The Swedish intervention evaluated by Bhalotra et al. (2017), which included both home visits and infant care clinics, also showed long-term health improvements, as reported above. 
problems in accessing clean water. ${ }^{26}$ Additionally, new problems are emerging, such as that of hydraulic fracturing (fracking). ${ }^{25}$

Lastly, a separate strand of targeted programmes do not provide specific inputs (such as health or child care), but rather monetary resources or improved environments. On the one hand, cash transfers to underprivileged families have been shown to impact children's longterm health. For example, Aizer et al. (2016) have studied the Mothers' Pension Program in the US (1911-1931) and found that the children of poor mothers who were accepted into the programme were less likely to be underweight and more likely to live longer than the children of those mothers who were rejected from it. Moreover, the programme successfully targeted inequality as the effects were larger for the poorest families. Also in the US, Hoynes et al. (2016) find that access to Food Stamps in the 1960s, in the period between conception and age 5, had a positive effect on adult weight, height, likelihood of disability and metabolic syndrome. As a programme targeted at those living in poverty, it also helped reduce health inequalities. On the other hand, the evidence is more mixed in relation to the health impacts of changes in the neighbourhood environment. ${ }^{27}$

The evidence reviewed in this section shows that early years interventions of various content, especially those targeting poor families, have the potential to improve life course health. While there is a robust body of evidence on causal impacts, particular knowledge about mechanisms is scarce. Understanding why and for whom early interventions improve health across the life course is an important avenue of future work. It requires going beyond reducedform evidence to estimate more structural relationships, in particular adult health production functions incorporating early life inputs. This would build on a body of literature from the early $21^{\text {st }}$ century which has shown the role of early childhood development in the production of adult health, in all its dimensions: cognitive, socioemotional and health development (Conti et al., 2010, 2011; Conti and Hansman, 2013; Kaestner and Callison, 2011; Mendolia and Walker, 2014; Bijwaard et al., 2015; Case and Paxson, 2010). A first example of this type of analysis is provided in Conti et al. (2016), who develop a novel dynamic mediation analysis to study the mechanisms through which the Perry Preschool and the Abecedarian programmes improved adult health. They show a significant role played by improved childhood development, above and beyond the effects of experimentally enhanced adult socioeconomic status. In particular, reduced externalising behaviour at ages 7-9 years and improved task orientation in the first two years of life were the key drivers of reductions in smoking and hypertension in the Perry and Abecedarian, respectively.

\section{Interactions}

The previous sections documented the available empirical evidence on the effects of shocks and interventions during the prenatal and childhood period on adult health. An unequivocal finding is that children's early environment can have lasting effects. One particular feature is

\footnotetext{
${ }^{26}$ For example, Currie et al. (2013) find in-utero exposure of these families to contaminated water in New Jersey to negatively affect birth outcomes. 25 Currie et al. (2017) find in-utero exposure to fracking to negatively affect birth outcomes. Due to the recency of these events, long-term effects are not yet known.

27 While Ludwig et al. (2013b) find long-term improvements in physical and mental health (for females only) from changes to better neighbourhoods for low-income families in the U.S., Gould et al. (2011) find no long-term health impacts from changes in the early environment in Israel.
} 
that the evidence discussed mostly considers one shock or one intervention, at a specific point in time. Yet, multiple shocks of different nature (ranging from environmental to socioeconomic) can affect human development since the prenatal period, and very little is known about their consequences. Along the same lines, pregnant women, fetuses and children might be exposed to different policies at different stages of development. In the theoretical framework, this amounts to studying the role of dynamic complementarities between shocks $(\varepsilon)$ and investments $(I)$ at different time points in the development process.

Research in these areas is rather limited, partly because of the demanding requirements both in terms of data and research design. Data is very scarce on cohorts who experienced both shocks and interventions in a quasi-random fashion, and also spans long enough through their life in order to observe long-term effects on health. Most of the existing empirical applications use data from developing countries and focus on short-term effects. ${ }^{28}$ An exception is a historical study by Arthi (2018), who explores whether in-utero exposure to a negative shock, the 1930s Dust Bowl in the US, can be remediated by the subsequent implementation of the New Deal. Looking at physical disability and vision and hearing difficulties, she provides evidence supporting this remediating mechanism.

Campbell et al. (2014) is the only study reporting evidence from a sequential randomisation in the Abecedarian intervention, where both the treatment and the control group in the preschool stage (ages 0-5) were re-randomised to the school stage (ages 6-8). The authors show that the children who were in the school-age treatment (irrespective of the preschool treatment allocation) didn't have significant benefits for their adult health. Another study is that by Rossin-Slater and Wu"st (2016), who study the interaction between a nurse home visiting program (targeting children at birth) and a childcare program (targeting children at 3 years of age) that occurred between 1930s and 1950s, using administrative data from Denmark. Although they find significant positive effects, overall gains from the childcare programme were greater for those unexposed to the nurse home visiting intervention. This seems to run counter to the concept of dynamic complementarity, since the productivity of the later intervention was smaller for those with higher initial stock due to the birth intervention.

Hence, work on the interaction of shocks and policies in different periods within a life course model of health production is a particularly important avenue for future research.

\section{Conclusion}

This chapter reviews the literature in economics on the developmental origins of health. An overview of the available theoretical frameworks through which the long reach of early circumstances can be understood, and through which empirical findings can be contextualized has been provided. It has also been shown how the frameworks employed to study health production in adulthood and child development have been developed somewhat separately, and an overarching comprehensive theory of health capital production across the entire life course is still fundamentally lacking.

A review of the evidence on the long-term health effects of early-life health shocks of various nature, ranging from environmental, to nutritional, to economic shocks proposed that

\footnotetext{
28 See, for example, a handful of working papers: Adhvaryu et al. (2018); Aguilar and Vicarelli (2015); Duque et al. (2016); Malamud et al. (2016).
} 
these shocks have persistent effects on different measures of health (ranging from height to mortality), with males usually more affected than females whenever gender differences were analysed. ${ }^{29}$ At the same time, various policies and interventions of different content and delivery format (ranging from health insurance coverage to home visiting programs) have been effective at improving long-term health, with greater gains for the most socioeconomically disadvantaged groups and for earlier exposures.

The literature has provided robust causal evidence on long-term effects. However, this is mostly limited to reduced-form impacts of single shocks or policies. Several unknowns remain, and represent important avenues of future research. First, researchers' understanding of the mechanisms through which shocks, investments, and policies interact is just in its infancy. This requires estimating more structural relationships via health production functions, which have more demanding data requirements. Second, the public health literature has suggested the importance of the preconception period for future health (Stephenson et al., 2018). Studies in economics usually don't examine exposures occurring earlier than the pregnancy period. Third, more rigorous life-cycle cost-benefits analyses of early interventions would be beneficial. ${ }^{30}$ Fourth, more sensitive measures of health phenotypes ${ }^{31}$ and underlying biological processes (including genetic and epigenetic markers) would be beneficial in disentangling the various mechanisms through which early shocks and interventions affect life course health.

\section{Further Reading}

Almond, D., Currie, J., and Duque, V. (forthcoming). Childhood circumstances and adult outcomes: Act II. Journal of Economic Literature.

Braveman, P., Egerter, S., and Williams, D. R. (2011). The social determinants of health: Coming of age. Annual Review of Public Health, 32, 381-398.

Conti, G. and Heckman, J.J., 2014. Economics of child well-being. In Handbook of child wellbeing (pp. 363-401). Springer, Dordrecht.

Currie, J. and Almond, D., 2011. Human capital development before age five. In Handbook of labor economics (Vol. 4, pp. 1315-1486). Elsevier.

Deaton, A. (2003). Health, inequality, and economic development. Journal of Economic Literature, 41(1), 113-158.

Elango, S., Garc'1a, J.L., Heckman, J.J. and Hojman, A., 2015. Early childhood education (No. w21766). National Bureau of Economic Research.

Fogel, R.W., 2004. The escape from hunger and premature death, 1700-2100: Europe, America, and the Third World (Vol. 38). Cambridge University Press.

Halfon, N. et al. (2018). Handbook of Life Course Health Development. Springer.

Heckman, J. J., and Mosso, S. (2014). The economics of human development and social mobility. Annual Review of Economics, 6(1), 689-733.

\footnotetext{
${ }^{29}$ Studying on a more systematic basis the presence of, and the possible reasons behind, gender differences, is also an important avenue of future research.

30 A prototype is Garc'ia et al. (2016). Some papers perform simple cost-benefits analyses - see e.g. Bu“'tikofer et al. (2015).

31 See for example Conti et al. (2018) who use unique data from ultrasound scans to study fetal development.
} 
Hertzman, C. and Boyce, T., 2010. How experience gets under the skin to create gradients in developmental health. Annual Review of Public Health, 31, pp.329-347.

\section{References}

Adhvaryu, A., Nyshadham, A., Molina, T., and Tamayo, J. (2018). Helping children catch up: Early life shocks and the PROGRESA experiment. Working Paper 24848, National Bureau of Economic Research.

Aguilar, A. and Vicarelli, M. (2015). El Niño and Mexican children: Medium-term effects of early-life weather shocks on cognitive and health outcomes. Mimeo, Harvard University.

Aizer, A., Eli, S., Ferrie, J., and Lleras-Muney, A. (2016). The long-run impact of cash transfers to poor families. American Economic Review, 106(4):935-971.

Akbulut-Yuksel, M. (2017). War during childhood: The long run effects of warfare on health. Journal of Health Economics, 53:117-130.

Almond, D. (2006). Is the 1918 influenza pandemic over? Long-term effects of in utero influenza exposure in the post-1940 US population. Journal of Political Economy, 114(4):672-712. Almond, D., Currie, J., and Duque, V. (2017). Childhood circumstances and adult outcomes: Act II. Working Paper 23017, National Bureau of Economic Research.

Almond, D., Edlund, L., and Palme, M. (2009). Chernobyl's subclinical legacy: prenatal exposure to radioactive fallout and school outcomes in Sweden. The Quarterly Journal of Economics, 124(4):1729-1772.

Almond, D. and Mazumder, B. (2005). The 1918 influenza pandemic and subsequent health outcomes: An analysis of SIPP data. American Economic Review, 95(2):258-262.

Almond, D. and Mazumder, B. (2011). Health capital and the prenatal environment: The effect of Ramadan observance during pregnancy. American Economic Journal: Applied Economics, 3(4):56-85.

Almond, D. and Mazumder, B. (2013). Fetal origins and parental responses. Annual Review of Economics, 5(1):37-56.

Alsan, M. and Goldin, C. (2015). Watersheds in infant mortality: The role of effective water and sewerage infrastructure, 1880 to 1915. Working Paper 21263, National Bureau of Economic Research.

Anderson, D. M., Charles, K. K., and Rees, D. I. (2018). Public health efforts and the decline in urban mortality. Working Paper 25027, National Bureau of Economic Research.

Arthi, V. (2018). "The dust was long in settling": Human capital and the lasting impact of the American Dust Bowl. Journal of Economic History, 78(1):196-230.

Banerjee, A., Duflo, E., Postel-Vinay, G., and Watts, T. (2010). Long-run health impacts of income shocks: Wine and phylloxera in nineteenth-century France. The Review of Economics and Statistics, 92(4):714-728.

Barker, D. and Osmond, C. (1987). Death rates from stroke in england and wales predicted from past maternal mortality. Br Med J (Clin Res Ed), 295(6590):83-86.

Barker, D. J. and Osmond, C. (1986). Infant mortality, childhood nutrition, and ischaemic heart disease in england and wales. The Lancet, 327(8489):1077-1081. 
Barker, D. J., Osmond, C., and Law, C. (1989a). The intrauterine and early postnatal origins of cardiovascular disease and chronic bronchitis. Journal of Epidemiology $\mathcal{E}$ Community Health, 43(3):237-240.

Barker, D. J., Osmond, C., Winter, P., Margetts, B., and Simmonds, S. J. (1989b). Weight in infancy and death from ischaemic heart disease. The Lancet, 334(8663):577-580.

Beach, B., Ferrie, J. P., and Saavedra, M. H. (2018). Fetal shock or selection? The 1918 influenza pandemic and human capital development. Working Paper 24725, National Bureau of Economic Research.

Becker, G. S. (1962). Investment in Human Capital: A Theoretical Analysis. Journal of Political Economy, 70(5):9-49.

Becker, G. S. (1964). Human Capital. National Bureau of Economic Research, New York, NY.

Becker, G. S. (1965). A Theory of the Allocation of Time. The Economic Journal, 75(299):493- 517.

Becker, G. S. (2007). Health as human capital: synthesis and extensions. Oxford Economic Papers, 59(3):379-410.

Becker, G. S. and Murphy, K. M. (1988). A Theory of Rational Addiction. Journal of Political Economy, 96(4):675-700.

Behrman, J. R. and Rosenzweig, M. R. (2004). Returns to birthweight. The Review of Economics and Statistics, 86(2):586-601.

Ben-Porath, Y. (1967). The production of human capital and the life cycle of earnings. Journal of Political Economy, 75(4, Part 1):352-365.

Bengtsson, T. and Helgertz, J. (2015). The long lasting influenza: The impact of fetal stress during the 1918 influenza pandemic on socioeconomic attainment and health in Sweden 19682012. Discussion Paper 9327, IZA Institute of Labor Economics.

Bhalotra, S., Karlsson, M., and Nilsson, T. (2017). Infant health and longevity: Evidence from a historical intervention in Sweden. Journal of the European Economic Association, 15(5):1101-1157. Bhalotra, S. and Venkataramani, A. S. (2015). Shadows of the captain of the men of death: Health innovation, human capital investment, and institutions. Mimeo, Available at SSRN: https:/ / ssrn.com/abstract=1940725.

Bharadwaj, P., Lundborg, P., and Rooth, D.-O. (2018). Birth weight in the long run. Journal of Human Resources, 53(1):189-231.

Bharadwaj, P., Zivin, J. G., Mullins, J. T., and Neidell, M. (2016). Early-life exposure to the great smog of 1952 and the development of asthma. American Journal of Respiratory and Critical Care Medicine, 194(12):1475-1482.

Bijwaard, G. E., van Kippersluis, H., and Veenman, J. (2015). Education and health: The role of cognitive ability. Journal of Health Economics, 42:29-43.

Black, S. E., Bu“tikofer, A., Devereux, P. J., and Salvanes, K. G. (2017). This is only a test?Longrun impacts of prenatal exposure to radioactive fallout. Working Paper 18987, National Bureau of Economic Research.

Black, S. E., Devereux, P. J., and Salvanes, K. G. (2007). From the cradle to the labor market? the effect of birth weight on adult outcomes. The Quarterly Journal of Economics, 122(1):409- 439. 
B"orsch-Supan, A. H. and Ju"rges, H. (2011). Disability, pension reform and early retirement in Germany. Working Paper 17079, National Bureau of Economic Research.

Boudreaux, M. H., Golberstein, E., and McAlpine, D. D. (2016). The long-term impacts of Medicaid exposure in early childhood: Evidence from the program's origin. Journal of Health Economics, 45:161-175.

Bowlby, J. (1969). Attachment and Loss: Attachment.-1969.-(RUidnr.: M102591232). Basic books. Bozzoli, C., Deaton, A., and Quintana-Domeque, C. (2009). Adult height and childhood disease. Demography, 46(4):647-669.

Brown, D. W., Kowalski, A. E., and Lurie, I. Z. (2015). Medicaid as an investment in children: What is the long-term impact on tax receipts? Working Paper 20835, National Bureau of Economic Research.

Brown, R. and Thomas, D. (2016). On the long term effects of the 1918 US influenza pandemic. mimeo, Duke University.

Bu“tikofer, A., Løken, K. V., and Salvanes, K. G. (2015). Long-term consequences of access to well-child visits. Discussion Paper 29/2015, NHH Dept. of Economics.

Bu'tikofer, A. and Salvanes, K. G. (2018). Disease control and inequality reduction: Evidence from a tuberculosis testing and vaccination campaign. Discussion Paper 11709, IZA Institute of Labor Economics.

Campbell, F., Conti, G., Heckman, J. J., Moon, S. H., Pinto, R., Pungello, E., and Pan, Y. (2014). Early childhood investments substantially boost adult health. Science, 343(6178):1478-1485.

Carneiro, P., Crawford, C., Goodman, A., and Centre for the Economics of Education (Great Britain) (2007). The impact of early cognitive and non-cognitive skills on later outcomes. Technical report, Centre for the Economics of Education, London School of Economics, London. OCLC: 183819510.

Carneiro, P. and Ginja, R. (2014). Long-term impacts of compensatory preschool on health and behavior: Evidence from head start. American Economic Journal: Economic Policy, 6(4):135-73.

Case, A. and Deaton, A. (2015). Rising morbidity and mortality in midlife among white nonhispanic americans in the 21st century. Proceedings of the National Academy of Sciences, 112(49):15078-15083.

Case, A. and Deaton, A. S. (2005). Broken down by work and sex: How our health declines. In Analyses in the Economics of Aging, pages 185-212. University of Chicago Press.

Case, A., Lubotsky, D., and Paxson, C. (2002). Economic status and health in childhood: The origins of the gradient. American Economic Review, 92(5):1308-1334.

Case, A. and Paxson, C. (2010). Causes and consequences of early-life health. Demography, 47(1):S65-S85.

Chetty, R., Stepner, M., Abraham, S., Lin, S., Scuderi, B., Turner, N., Bergeron, A., and Cutler, D. (2016). The association between income and life expectancy in the united states, 2001-2014. Jama, 315(16):1750-1766.

Cohort and Longitudinal Studies Enhancement Resources (2017). Harmonised Height, Weight and BMI in Five Longitudinal Cohort Studies: National Child Development Study, 1970 British Cohort Study and Millennium Cohort Study. 
Cohort and Longitudinal Studies Enhancement Resources (2018a). Harmonised SocioEconomic Measures in Four Longitudinal Cohort Studies: 1970 British Cohort Study.

Cohort and Longitudinal Studies Enhancement Resources (2018b). Harmonised SocioEconomic Measures in Four Longitudinal Cohort Studies: Millennium Cohort Study.

Cohort and Longitudinal Studies Enhancement Resources (2018c). Harmonised SocioEconomic Measures in Four Longitudinal Cohort Studies: National Child Development Study.

Condliffe, S. and Link, C. R. (2008). The relationship between economic status and child health: evidence from the united states. American Economic Review, 98(4):1605-18.

Conti, G., Fru“hwirth-Schnatter, S., Heckman, J. J., and Piatek, R. (2014). Bayesian exploratory factor analysis. Journal of Econometrics, 183(1):31-57.

Conti, G. and Hansman, C. (2013). Personality and the education-health gradient: A note on "Understanding differences in health behaviors by education". Journal of Health Economics, 32(2):480-485.

Conti, G., Hanson, M., Inskip, H., Crozier, S., Cooper, C., and Godfrey, K. (2018). Beyond birth weight: The origins of human capital. Technical report, Human Capital and Economic Opportunity Working Group.

Conti, G., Heckman, J. J., and Pinto, R. (2016). The effects of two influential early childhood interventions on health and healthy behaviour. The Economic Journal, 126(596):F28-F65.

Conti, G., Heckman, J. J., and Urzua, S. (2010). The education-health gradient. American Economic Review: Papers \& Proceedings, 100(2):234-238.

Conti, G., Heckman, J. J., and Urzua, S. (2011). Early endowments, education, and health. Working Paper 2011-001, Human Capital and Economic Opportunity: A Global Working Group.

Conti, G., Morris, S., Melnychuk, M., and Pizzo, E. (2017). The economic costs of child maltreatment in the uk. London: NSPCC.

Cropper, M. L. (1977). Health, Investment in Health, and Occupational Choice. Journal of Political Economy, 85(6):1273-1294.

Cunha, F. and Heckman, J. J. (2007). The technology of skill formation. American Economic Review, 97(2):31-47.

Cunha, F., Heckman, J. J., and Schennach, S. (2010). Estimating the Technology of Cognitive and Noncognitive Skill Formation. Econometrica, 78(3):883-931.

Currie, J. and Almond, D. (2011). Human capital development before age five. In Card, D. and Ashenfelter, O., editors, Handbook of Labor Economics, volume 4, pages 1315-1486. Elsevier.

Currie, J., Graff Zivin, J., Meckel, K., Neidell, M., and Schlenker, W. (2013). Something in the water: Contaminated drinking water and infant health. Canadian Journal of Economics/Revue canadienne d'economique, 46(3):791-810.

Currie, J., Greenstone, M., and Meckel, K. (2017). Hydraulic fracturing and infant health: New evidence from Pennsylvania. Science Advances, 3(12):e1603021.

Currie, J. and Moretti, E. (2003). Mother's education and the intergenerational transmission of human capital: Evidence from college openings. The Quarterly Journal of Economics, 118(4):1495-1532. 
Currie, J. and Moretti, E. (2007). Biology as destiny? Short-and long-run determinants of intergenerational transmission of birth weight. Journal of Labor Economics, 25(2):231-264.

Currie, J. and Schwandt, H. (2016). Mortality inequality: The good news from a county-level approach. Journal of Economic Perspectives, 30(2):29-52.

Currie, J., Stabile, M., Manivong, P., and Roos, L. L. (2010). Child health and young adult outcomes. Journal of Human Resources, 45(3):517-548.

Currie, J., Zivin, J. G., Mullins, J., and Neidell, M. (2014). What do we know about short-and long-term effects of early-life exposure to pollution? Annual Review of Resource Economics, 6(1):217-247.

Cutler, D. and Miller, G. (2005). The role of public health improvements in health advances: The twentieth-century United States. Demography, 42(1):1-22.

Cutler, D. M., Miller, G., and Norton, D. M. (2007). Evidence on early-life income and latelife health from America's Dust Bowl era. Proceedings of the National Academy of Sciences, 104(33):13244-13249.

Dalgaard, C.-J. and Strulik, H. (2014). Optimal aging and death: Understanding the Preston curve. Journal of the European Economic Association, 12(3):672-701.

Dalgaard, C.-J. L., Hansen, C. W., and Strulik, H. (2017). Accounting for Fetal Origins: Health Capital vs. Health Deficits. Technical Report 17-11.

Danzer, A. M. and Danzer, N. (2016). The long-run consequences of chernobyl: Evidence on subjective well-being, mental health and welfare. Journal of Public Economics, 135:47-60.

Dardanoni, V. and Wagstaff, A. (1987). Uncertainty, inequalities in health and the demand for health. Journal of Health Economics, 6(4):283-290.

Dardanoni, V. and Wagstaff, A. (1990). Uncertainty and the demand for medical care. Journal of Health Economics, 9(1):23-38.

Datta Gupta, N. (2018). Maternity leave versus early childcare-what are the long-term consequences for children? IZA World of Labor.

Derrick, V. (1927). Observations on (1) errors of age in the population statistics of england and wales, and (2) the changes in mortality indicated by the national records. Journal of the Institute of Actuaries, 58(2):117-159.

Doyle Jr, J. J. and Aizer, A. (2018). Economics of child protection: Maltreatment, foster care, and intimate partner violence. Annual Review of Economics, 10:87-108.

Duque, V., Rosales-Rueda, M., and Sanchez, F. (2016). How do early-life shocks interact with subsequent human-capital investments? Evidence from administrative data. Mimeo, University of Michigan.

Ehrlich, I. and Chuma, H. (1990). A Model of the Demand for Longevity and the Value of Life Extension. Journal of Political Economy, 98(4):761-782.

Fletcher, J. M. (2009). Childhood mistreatment and adolescent and young adult depression. Social Science \& Medicine, 68(5):799-806.

Fletcher, J. M. (2018). Examining the long-term mortality effects of early health shocks. Applied Economics Letters, pages 1-7. 
Fogel, R. W. (1997). New findings on secular trends in nutrition and mortality: some implications for population theory. Handbook of population and family economics, 1:433-481.

Forsdahl, A. (1973). Momenter til belysning av den høye dødelighet i finnmark fylke. kan den høye dødelighet i dag være en senfølge av meget $d^{\circ}$ arlige levevilkªr i barne-og ungdomsalderen? Tidsskrift for den norske lægeforening, 93(10):661-667.

Forsdahl, A. (2002). Observations throwing light on the high mortality in the county of finnmark. is the high mortality today a late effect of very poor living conditions in childhood and adolescence? International journal of epidemiology, 31(2):302-308.

French, E. (2005). The effects of health, wealth, and wages on labour supply and retirement behaviour. The Review of Economic Studies, 72(2):395-427.

Galama, T. J. (2015). A contribution to health-capital theory. Technical Report 2015-008, Human Capital and Economic Opportunity Global Working Group.

Galama, T. J., Lleras-Muney, A., and van Kippersluis, H. (2018). The effect of education on health and mortality: A review of experimental and quasi-experimental evidence. Working Paper 24225, National Bureau of Economic Research.

Galama, T. J. and Van Kippersluis, H. (2015). A theory of socioeconomic disparities in health over the life cycle. Technical Report 2013-016.

Garc'ia, J. L., Heckman, J. J., Leaf, D. E., and Prados, M. J. (2016). The life-cycle benefits of an influential early childhood program. Working Paper 22993, National Bureau of Economic Research.

Gayle, G.-L., Golan, L., and Soytas, M. A. (2017). What is the Source of the Intergenerational Correlation in Earnings? Technical report.

Gilleskie, D. (2008). Health Capital: Theory and Empirical Evidence. In Sloan, F. A. and Kasper, H., editors, Incentives and Choice in Health Care, pages 51-80. The MIT Press.

Gluckman, P. D. and Hanson, M. A. (2006). The developmental origins of health and disease. Springer.

Goodman-Bacon, A. (2016). The long-run effects of childhood insurance coverage: Medicaid implementation, adult health, and labor market outcomes. Working Paper 22899, National Bureau of Economic Research.

Gould, E. D., Lavy, V., and Paserman, M. D. (2011). Sixty years after the magic carpet ride: The long-run effect of the early childhood environment on social and economic outcomes. The Review of Economic Studies, 78(3):938-973.

Grossman, M. (1972a). The Demand for Health: A Theoretical and Empirical Investigation. National Bureau of Economic Research; distributed by Columbia University Press, New York.

Grossman, M. (1972b). On the concept of health capital and the demand for health. Journal of Political Economy, 80(2):223-255.

Grossman, M. (2000). The human capital model. In Handbook of Health Economics, volume 1, pages 347-408. Elsevier.

Halliday, T., Mazumder, B., and Wong, A. (2018). Intergenerational health mobility in the us. Working Paper 11304, IZA Institute of Labor Economics. 
Halliday, T. J., He, H., Ning, L., and Zhang, H. (2016). Health investment over the life cycle. Technical report.

Havari, E. and Mazzonna, F. (2015). Can we trust older people's statements on their childhood circumstances? Evidence from SHARELIFE. European Journal of Population, 31(3):233-257.

Havari, E. and Peracchi, F. (2017). Growing up in wartime: Evidence from the era of two world wars. Economics \& Human Biology, 25:9-32.

Heckman, J. J. (2007). The economics, technology, and neuroscience of human capability formation. Proceedings of the National Academy of Sciences, 104(33):13250-13255.

Herbst, C. M. (2017). Universal child care, maternal employment, and children's long-run outcomes: Evidence from the US Lanham Act of 1940. Journal of Labor Economics, 35(2):519564.

Hjort, J., Sølvsten, M., and Wu“st, M. (2017). Universal investment in infants and long-run health: Evidence from Denmark's 1937 home visiting program. American Economic Journal: Applied Economics, 9(4):78-104.

House, J. S., Lepkowski, J. M., Kinney, A. M., Mero, R. P., Kessler, R. C., and Herzog, A. R. (1994). The Social Stratification of Aging and Health. Journal of Health and Social Behavior, 35(3):213.

Hoynes, H., Schanzenbach, D. W., and Almond, D. (2016). Long-run impacts of childhood access to the safety net. American Economic Review, 106(4):903-934.

Johnston, D. W., Schurer, S., and Shields, M. A. (2013). Exploring the intergenerational persistence of mental health: Evidence from three generations. Journal of Health Economics, 32(6):1077-1089.

Kaestner, R. and Callison, K. (2011). Adolescent cognitive and noncognitive correlates of adult health. Journal of Human Capital, 5(1):29-69.

Kenkel, D. S. (2000). Prevention. In Handbook of Health Economics, volume 1 Part B, pages 16751720. Elsevier.

Kermack, W. O., McKendrick, A. G., McKinlay, P. L., et al. (1934). Death-rates in great britain and sweden. some general regularities and their significance. Lancet, pages 698-703.

Kesternich, I., Siflinger, B., Smith, J. P., and Winter, J. K. (2014). The effects of World War II on economic and health outcomes across Europe. Review of Economics and Statistics, 96(1):103-118. Kesternich, I., Siflinger, B., Smith, J. P., and Winter, J. K. (2015). Individual behaviour as a pathway between early-life shocks and adult health: Evidence from hunger episodes in postwar Germany. The Economic Journal, 125(588):F372-F393.

Kesztenbaum, L. and Rosenthal, J.-L. (2017). Sewers' diffusion and the decline of mortality: The case of Paris, 1880-1914. Journal of Urban Economics, 98:174-186.

Kuh, D. and Smith, G. D. (1993). When is mortality risk determined? historical insights into a current debate. Social history of medicine, 6(1):101-123.

Kunst, A. E., Bos, V., Andersen, O., Cardano, M., Costa, G., Harding, S., Hemstr"om, O., Layte," R., Regidor, E., Reid, A., et al. (2004). Monitoring of trends in socioeconomic inequalities in mortality: Experiences from a European project. Demographic Research, 2:229-254. 
Lakner, C. and Milanovic, B. (2016). Global income distribution: From the fall of the Berlin Wall to the Great Recession. World Bank Economic Review, 30(2):203-232.

Lehmann, H. and Wadsworth, J. (2011). The impact of chernobyl on health and labour market performance. Journal of health economics, 30(5):843-857.

Lindeboom, M., Portrait, F., and Van den Berg, G. J. (2010). Long-run effects on longevity of a nutritional shock early in life: The Dutch potato famine of 1846-1847. Journal of Health Economics, 29(5):617-629.

Lleras-Muney, A. (2005). The relationship between education and adult mortality in the United States. The Review of Economic Studies, 72(1):189-221.

Ludwig, D. S., Rouse, H. L., and Currie, J. (2013a). Pregnancy weight gain and childhood body weight: A within-family comparison. PLoS medicine, 10(10):e1001521.

Ludwig, J., Duncan, G. J., Gennetian, L. A., Katz, L. F., Kessler, R. C., Kling, J. R., and Sanbonmatsu, L. (2013b). Long-term neighborhood effects on low-income families: Evidence from moving to opportunity. American Economic Review, 103(3):226-31.

Ludwig, J. and Miller, D. L. (2007). Does Head Start improve children's life chances? Evidence from a regression discontinuity design. The Quarterly Journal of Economics, 122(1):159-208.

Lu“hrmann, M. and Wilson, T. (2017). Long-run health and mortality effects of exposure to universal health care at birth. Mimeo, Institute for Fiscal Studies.

Mackenbach, J. P., Bos, V., Andersen, O., Cardano, M., Costa, G., Harding, S., Reid, A., Hemstr"om, O., Valkonen, T., and Kunst, A. E. (2003). Widening socioeconomic inequali-" ties in mortality in six Western European countries. International Journal of Epidemiology, 32(5):830837.

Malamud, O., Pop-Eleches, C., and Urquiola, M. (2016). Interactions between family and school environments: Evidence on dynamic complementarities? Working Paper 22112, National Bureau of Economic Research.

Mandal, B. and Powell, L. M. (2014). Child care choices, food intake, and children's obesity status in the United States. Economics \& Human Biology, 14:50-61.

Marmot, M. (2005). Social determinants of health inequalities. The lancet, 365(9464):1099-1104.

Marmot, M., Ryff, C. D., Bumpass, L. L., Shipley, M., and Marks, N. F. (1997). Social inequalities in health: Next questions and converging evidence. Social Science \& Medicine, 44(6):901-910.

Matsumoto, B. (2018). Family ruptures, stress, and the mental health of the next generation:

Comment. American Economic Review, 108(4-5):1253-1255.

Mazumder, B. (2007). How did schooling laws improve long-term health and lower mortality? wp 2006-23. Federal Reserve Bank of Chicago.

McCrary, J. and Royer, H. (2011). The effect of female education on fertility and infant health: Evidence from school entry policies using exact date of birth. American Economic Review, 101(1):158-95.

Mendolia, S. and Walker, I. (2014). The effect of noncognitive traits on health behaviours in adolescence. Health Economics, 23(9):1146-1158.

Miller, S. and Wherry, L. R. (2018). The long-term effects of early life Medicaid coverage. Journal of Human Resources. 
Muurinen, J.-M. (1982). Demand for health: A generalised Grossman model. Journal of Health Economics, 1(1):5-28.

Pappas, G., Queen, S., Hadden, W., and Fisher, G. (1993). The increasing disparity in mortality between socioeconomic groups in the United States, 1960 and 1986. New England journal of medicine, 329(2):103-109.

Persson, P. and Rossin-Slater, M. (2018a). Family ruptures, stress, and the mental health of the next generation. American Economic Review, 108(4-5):1214-1252.

Persson, P. and Rossin-Slater, M. (2018b). Family ruptures, stress, and the mental health of the next generation: Reply. American Economic Review, 108(4-5):1256-63.

Portrait, F., van Wingerden, T., and Deeg, D. (2017). Early life undernutrition and adult height: The Dutch famine of 1944-45. Economics \& Human Biology, 27:339-348.

Puentes, E., Wang, F., Behrman, J. R., Cunha, F., Hoddinott, J., Maluccio, J. A., Adair, L. S., Borja, J. B., Martorell, R., and Stein, A. D. (2016). Early life height and weight production functions with endogenous energy and protein inputs. Economics $\mathcal{E}$ Human Biology, 22:65-81.

Rossin-Slater, M. and Wu"st, M. (2016). What is the added value of preschool? Long-term impacts and interactions with a health intervention. Working Paper 22700, National Bureau of Economic Research.

Royer, H. (2009). Separated at girth: US twin estimates of the effects of birth weight. American Economic Journal: Applied Economics, 1(1):49-85.

Sama-Miller, E., Akers, L., Mraz-Esposito, A., Zukiewicz, M., Avellar, S., Paulsell, D., and

Del Grosso, P. (2016). Home visiting evidence of effectiveness review: Executive summary. Technical report, Office of Planning, Research and Evaluation, Administration for Children and Families, U.S. Department of Health and Human Services., Washington, DC.

Santavirta, N. and Santavirta, T. (2014). Child protection and adult depression: Evaluating the long-term consequences of evacuating children to foster care during world war ii. Health economics, 23(3):253-267.

Schiman, J. C., Kaestner, R., and Lo Sasso, A. T. (2017). Early childhood health shocks and adult wellbeing: Evidence from wartime Britain. Working Paper 23763, National Bureau of

Economic Research.

Schoeni, R. F., Freedman, V. A., and Martin, L. G. (2008). Why is late-life disability declining? The Milbank Quarterly, 86(1):47-89.

Scholte, R., van den Berg, G. J., Lindeboom, M., and Deeg, D. J. (2017). Does the size of the effect of adverse events at high ages on daily-life physical functioning depend on the economic conditions around birth? Health Economics, 26(1):86-103.

Scholte, R. S., Van den Berg, G. J., and Lindeboom, M. (2015). Long-run effects of gestation during the Dutch hunger winter famine on labor market and hospitalization outcomes. Journal of Health Economics, 39:17-30.

Stephenson, J., Heslehurst, N., Hall, J., Schoenaker, D. A., Hutchinson, J., Cade, J. E., Poston, L., Barrett, G., Crozier, S. R., Barker, M., et al. (2018). Before the beginning: nutrition and lifestyle in the preconception period and its importance for future health. The Lancet. 
Thompson, O. (2017). The long-term health impacts of Medicaid and CHIP. Journal of Health Economics, 51:26-40.

Todd, P. E. and Wolpin, K. I. (2003). On the specification and estimation of the production function for cognitive achievement. The Economic Journal, 113(485):F3-F33.

Trivers, R. L. and Willard, D. E. (1973). Natural selection of parental ability to vary the sex ratio of offspring. Science, 179(4068):90-92.

Van den Berg, G. J., Lindeboom, M., and Portrait, F. (2006). Economic conditions early in life and individual mortality. American Economic Review, 96(1):290-302.

Van den Berg, G. J., Pinger, P. R., and Schoch, J. (2016). Instrumental variable estimation of the causal effect of hunger early in life on health later in life. The Economic Journal, 126(591):465506.

Vollmer, S. and W'ojcik, J. (2017). The long-term consequences of the global 1918 influenza pandemic: A systematic analysis of 117 IPUMS international census data sets. Technical report, Courant Research Centre: Poverty, Equity and Growth-Discussion Papers.

Wagstaff, A. (1993). The demand for health: An empirical reformulation of the Grossman model. Health Economics, 2(2):189-198.

Wernerfelt, N., Slusky, D. J., and Zeckhauser, R. (2017). Second trimester sunlight and asthma: Evidence from two independent studies. American Journal of Health Economics, 3(2):227-253.

Wherry, L. R. and Meyer, B. D. (2016). Saving teens: Using a policy discontinuity to estimate the effects of Medicaid eligibility. Journal of Human Resources, 51(3):556-588.

Wherry, L. R., Miller, S., Kaestner, R., and Meyer, B. D. (2018). Childhood Medicaid coverage and later life health care utilization. The Review of Economics and Statistics, 100(2):287-302.

Yemelyanau, M., Amialchuk, A., and Ali, M. M. (2012). Evidence from the chernobyl nuclear accident: the effect on health, education, and labor market outcomes in belarus. Journal of labor research, 33(1):1-20.

Yi, J., Heckman, J. J., Zhang, J., and Conti, G. (2015). Early health shocks, intra-household resource allocation and child outcomes. The Economic Journal, 125(588):F347-F371.

Zweifel, P. and Breyer, F. (1997). Health Economics. Oxford University Press, Oxford, UK. 
Table A1: Summary of papers discussed in the main text - Shocks

\begin{tabular}{|c|c|c|c|c|}
\hline $\begin{array}{l}\text { Author (Year) } \\
\text { Country }\end{array}$ & Outcome and Exposure & Identification & Summary & Heterogeneity \\
\hline $\begin{array}{l}\text { Akbulut- } \\
\text { Yuksel (2017) } \\
\text { Germany }\end{array}$ & $\begin{array}{l}\text { Outcomes: BMI, obesity, } \\
\text { metabolic syndrome in } \\
\text { adulthood } \\
\text { Exposure: Intensity of WWII } \\
\text { destruction (war damage) } \\
\text { when in utero or young child } \\
\text { during WWII. }\end{array}$ & $\begin{array}{l}\text { Diff-in-Diff using city } \\
\text { and birth cohorts. }\end{array}$ & $\begin{array}{l}\text { War children exposed during prenatal or early } \\
\text { postnatal periods had about } 1 \text { point higher BMI and } 16 \\
\text { p.p. higher probability to be obese as adults, and more } \\
\text { likely to suffer from stroke, hypertension, diabetes and } \\
\text { cardiovascular disorders ( } 0.23 \text { s.d. increase in a } \\
\text { combined metabolic syndrome index) during } \\
\text { adulthood. }\end{array}$ & $\begin{array}{l}\text { Effects larger for } \\
\text { females and not } \\
\text { significant for } \\
\text { males. Also, larger } \\
\text { effects for urban } \\
\text { population. } \\
\text { Children of } \\
\text { mothers with less } \\
\text { than basic } \\
\text { education had } \\
\text { larger effects, but } \\
\text { not for father's } \\
\text { education. }\end{array}$ \\
\hline $\begin{array}{l}\text { Almond } \\
\text { (2006) USA }\end{array}$ & $\begin{array}{l}\text { Outcomes: Physical } \\
\text { disability preventing work } \\
\text { Exposure: Influenza exposure in } \\
\text { utero. }\end{array}$ & $\begin{array}{l}\text { Influenza pandemic and } \\
\text { cohort and geographic } \\
\text { variation in influenza } \\
\text { exposure }\end{array}$ & $\begin{array}{l}\text { The authors find that males in the cohort who } \\
\text { experience in-utero exposure to the pandemic had } \\
\text { increased rates ( } 1 \% \text { more likely) in physical disability. }\end{array}$ & None \\
\hline $\begin{array}{l}\text { Almond and } \\
\text { Mazumder } \\
\text { (2005) USA }\end{array}$ & $\begin{array}{l}\text { Outcomes: Self-reported health, } \\
\text { troubles with hearing, speaking, } \\
\text { lifting, walking, diabetes, stroke } \\
\text { Exposure: Influenza exposure in } \\
\text { utero. }\end{array}$ & $\begin{array}{l}\text { Influenza pandemic and } \\
\text { cohort and geographic } \\
\text { variation in influenza } \\
\text { exposure }\end{array}$ & $\begin{array}{l}\text { The authors find the } 1919 \text { cohort to be more likely to } \\
\text { self-report fair or poor health }(10 \%) \text {, or to have certain } \\
\text { functional limitations, such as troubles hearing }(19 \%) \text {, } \\
\text { speaking ( } 35 \%) \text {, lifting }(13 \%) \text {, and walking }(17 \%) \text {. } \\
\text { Stroke and diabetes were found more likely to occur } \\
\text { for this cohort as well. }\end{array}$ & None \\
\hline
\end{tabular}




\begin{tabular}{|c|c|c|c|c|}
\hline $\begin{array}{l}\text { Almond and } \\
\text { Mazumder } \\
\text { (2011) USA }\end{array}$ & $\begin{array}{l}\text { Outcomes: Birthweight in } \\
\text { Michigan (Long-term outcomes } \\
\text { for Uganda and Iraq ) } \\
\text { Exposure: Mother fasting during } \\
\text { pregnancy }\end{array}$ & $\begin{array}{l}\text { Observance of } \\
\text { Ramadan during } \\
\text { pregnancy for Muslim } \\
\text { and non-Muslim } \\
\text { mothers, using a Diff- } \\
\text { in-Diff } \\
\text { design }\end{array}$ & $\begin{array}{l}\text { The authors use the overlap of Ramadan with } \\
\text { pregnancy (and particular trimesters) and a measure of } \\
\text { exposure hours using the variation in daylight hours. } \\
\text { They find a significant negative effect on birthweight } \\
\text { for the first two trimesters and a negative insignificant } \\
\text { effect for the third trimester. Although significant, the } \\
\text { magnitudes are very low, around } 1 \text { percent decrease of } \\
\text { mean birth weight. }\end{array}$ & None \\
\hline $\begin{array}{l}\text { Arthi } \\
\text { USA }\end{array}$ & $\begin{array}{l}\text { Outcomes: Physical disability } \\
\text { and vision and hearing } \\
\text { problems } \\
\text { Exposure: Exposure to Dust } \\
\text { Bowl when in utero and during } \\
\text { childhood }\end{array}$ & $\begin{array}{l}\text { Diff-in-Diff using state } \\
\text { and birth cohorts. }\end{array}$ & $\begin{array}{l}\text { Although the Dust Bowl has generally strong negative } \\
\text { effects, especially for those exposed in utero, on } \\
\text { physical disability (about 1p.p.), but not on vision and } \\
\text { hearing problems, the implementation of the New Deal } \\
\text { is able to recover a large proportion of the damage. } \\
\text { This suggests that subsequent interventions can } \\
\text { remediate the effects of a negative early in life shock. }\end{array}$ & $\begin{array}{l}\text { The negative effect } \\
\text { is larger in boys } \\
\text { than in girls, and } \\
\text { significant only for } \\
\text { the boys. }\end{array}$ \\
\hline $\begin{array}{l}\text { Banerjee et al } \\
\text { (2010) France }\end{array}$ & $\begin{array}{l}\text { Outcomes: Adult height, life } \\
\text { expectancy, and other health } \\
\text { outcomes (exempt from } \\
\text { military due to health, myopia, } \\
\text { goiter, hernia, spinal problem, } \\
\text { epilepsy, low IQ, feeble, blind, } \\
\text { deaf) } \\
\text { Exposure: Income shock at year } \\
\text { of birth. }\end{array}$ & $\begin{array}{l}\text { Diff-in-Diff using } \\
\text { regional variation in } \\
\text { timing of phylloxera that } \\
\text { destroyed French } \\
\text { vineyards. }\end{array}$ & $\begin{array}{l}\text { The authors find an effect on height (1.8 millimeters), } \\
\text { but no effect on any other health outcome or life } \\
\text { expectancy. The income shock and corresponding } \\
\text { decline in nutrition affected body development, but } \\
\text { health status may have been protected by other factors } \\
\text { (e.g. public health). }\end{array}$ & None \\
\hline
\end{tabular}




\begin{tabular}{|c|c|c|c|c|}
\hline $\begin{array}{l}\text { Beach et al } \\
\text { (2018) USA }\end{array}$ & $\begin{array}{l}\text { Outcomes: Height, weight, } \\
\text { BMI } \\
\text { Exposure: Influenza exposure in } \\
\text { utero. }\end{array}$ & $\begin{array}{l}\text { Influenza pandemic } \\
\text { and cohort and } \\
\text { geographic variation in } \\
\text { influenza exposure }\end{array}$ & $\begin{array}{l}\text { The authors revisit the study of the } 1918 \text { influenza in } \\
\text { the US by enhancing the analysis using linked data. } \\
\text { This provides better geographical variation in } \\
\text { influenza exposure as it uses city-level information. } \\
\text { Moreover the authors correct for age heaping (fathers } \\
\text { of lower cognitive ability more likely to report ages } \\
\text { ending in } 0 \text { or 5) which biases the results in the } \\
\text { previous literature. While the authors find an effect on } \\
\text { education, they find no effects on height, weight or } \\
\text { BMI. }\end{array}$ & None \\
\hline $\begin{array}{l}\text { Behram and } \\
\text { Rosenzweig } \\
\text { (2004) USA }\end{array}$ & $\begin{array}{l}\text { Outcomes: Adult physical } \\
\text { characteristics }\end{array}$ & $\begin{array}{l}\text { Exogenous increase in } \\
\text { intrauterine nutrient } \\
\text { consumption, twin } \\
\text { fixed effects }\end{array}$ & $\begin{array}{l}\text { The authors find that increasing birthweight has no } \\
\text { effect on the child's obesity later in life. However, they } \\
\text { find that each additional 1lb there increases adult } \\
\text { height by } 0.6 \mathrm{in} \text {. }\end{array}$ & None \\
\hline $\begin{array}{l}\text { Bengtsson and } \\
\text { Helgertz (2015) } \\
\text { Sweden }\end{array}$ & $\begin{array}{l}\text { Outcomes: hospitalizations and } \\
\text { its duration (age between } 54 \\
\text { and 90), and mortality. } \\
\text { Exposure: Influenza exposure in } \\
\text { utero. }\end{array}$ & $\begin{array}{l}\text { Cohort and geographic } \\
\text { variation in influenza } \\
\text { exposure }\end{array}$ & $\begin{array}{l}\text { Males born in the first quarter of } 1919 \text { (exposed in the } \\
\text { fetal stage) to the pandemic to be } 3.6 \% \text { more likely to } \\
\text { be hospitalised and } 3.8 \% \text { for mortality. For females, } \\
\text { there was only a significant } 2.9 \% \text { higher risk for } \\
\text { hospitalisations. }\end{array}$ & $\begin{array}{l}\text { Hospitalisation } \\
\text { overall effect } \\
\text { similar between } \\
\text { men and women. } \\
\text { However, for boys } \\
\text { concentrated in } \\
\text { 2nd trimester, } \\
\text { while for girls } \\
\text { concentrated in } \\
\text { 3rd. Mortality } \\
\text { effects only for } \\
\text { men. }\end{array}$ \\
\hline
\end{tabular}




\begin{tabular}{|c|c|c|c|c|}
\hline $\begin{array}{l}\text { Bharadwaj et al } \\
\text { (2016) UK }\end{array}$ & $\begin{array}{l}\text { Outcomes: Adult asthma } \\
\text { development } \\
\text { Exposure: Prenatal or during the } \\
\text { first year of life air pollution }\end{array}$ & $\begin{array}{l}\text { Exogenous exposure to } \\
\text { air pollution due to the } \\
1952 \text { Great Smog of } \\
\text { London }\end{array}$ & $\begin{array}{l}\text { The authors examine the increase in likelihood of } \\
\text { asthma development during childhood and adulthood, } \\
\text { as a result of the unexpected exposure to air pollution } \\
\text { around birth. They use a sample of children born in } \\
\text { London (which suffered by the smog) and outside } \\
\text { London, and the various cohorts exposed prenatally, } \\
\text { and in subsequent years of life. Their main finding is } \\
\text { that exposure during the first year or life has a } \\
\text { significant effect on the likelihood of childhood asthma } \\
\text { (19 p.p.), and an effect on adulthood asthma which is } \\
\text { not significant. The effects of in utero exposure are also } \\
\text { not significant, and much smaller in magnitude. }\end{array}$ & None \\
\hline $\begin{array}{l}\text { Black et al } \\
\text { (2017) Norway }\end{array}$ & $\begin{array}{l}\text { Outcomes: Adult height } \\
\text { Exposure: Nuclear radiation } \\
\text { exposure in utero. }\end{array}$ & $\begin{array}{l}\text { Regional fallout by } \\
\text { wind, rainfall and } \\
\text { topography across and } \\
\text { over time. In addition, } \\
\text { sibling fixed effects. }\end{array}$ & $\begin{array}{l}\text { Although significant effects are found for IQ, } \\
\text { education and earning, the effect on height is much } \\
\text { weaker and not consistent across specifications, } \\
\text { suggesting that the effect of radiation in concentrated } \\
\text { on cognitive ability and not on development. }\end{array}$ & $\begin{array}{l}\text { No heterogeneous } \\
\text { effects for child's } \\
\text { mother education. }\end{array}$ \\
\hline
\end{tabular}




\begin{tabular}{lll}
\hline Brown and & $\begin{array}{l}\text { Outcomes: Physical } \\
\text { disability preventing work }\end{array}$ & after controlling for \\
phomasental background, & pare \\
(2016) USA & Exposure: Influenza exposure in & there are no effects
\end{tabular}

The authors argue that in-utero exposure to the

None

(2016) USA utero.

influenza pandemic is not randomly assigned. In fact, exposed families happened to be different than unexposed ones on several observables. For example, father of 'treated' individuals were found more likely to have a lower socio-economic status, less likely to be white, more likely to be older or have lower income, less likely to be world war two veterans than father of unexposed individuals. When controlling for these observables, they find the effect of the pandemic exposure to be statistically insignificant.

Cutler et al Outcomes: Health in late life, (2007) USA diabetes, heart condition, high blood pressure, chronic lung disease, psychiatric condition, stroke, arthritis, disability, height, bmi

Exposure: Great Depression and Dust Bowl exposure in utero.
Exposure to the economic The authors use crop yield, income and unemployment conditions among cohorts to capture the effects of the economic conditions controlling for birth cohort effects for the children of farmers. No significant effect is found in any of the health outcomes examined.
No effects founcfor neither for nonfarmers nor farmers.

\begin{tabular}{|c|c|c|c|c|}
\hline $\begin{array}{l}\text { Danzer and } \\
\text { Danzer (2016) } \\
\text { Ukraine }\end{array}$ & $\begin{array}{l}\text { Outcomes: depression and } \\
\text { anxiety, subjective survival } \\
\text { probabilities; } \\
\text { Exposure: sub-clinical radiation } \\
\text { doses }\end{array}$ & $\begin{array}{l}\text { Regional variation in } \\
\text { exposure due to } 1986 \\
\text { Chernobyl accident; } \\
\text { region, settlement, year } \\
\text { and month fixed } \\
\text { effects }\end{array}$ & $\begin{array}{l}20 \text { years after the accident, the authors find that a one } \\
\text { unit increase of natural background radiation increases } \\
\text { the likelihood of mental disorder diagnostics (by } 1.7 \\
\text { p.p. in the low-dose population), and reduces expected } \\
\text { survival probability (by } 7.5 \text { p.p.). }\end{array}$ & None \\
\hline $\begin{array}{l}\text { Fletcher } \\
\text { (2018) USA }\end{array}$ & $\begin{array}{l}\text { Outcomes: mortality; Exposure: } \\
\text { Influenza exposure in utero. }\end{array}$ & $\begin{array}{l}\text { Cohort variation in } \\
\text { influenza exposure }\end{array}$ & $\begin{array}{l}\text { The author explores whether differential exposure to } \\
\text { the pandemic (post-natal vs at birth and 3rd trimester } \\
\text { vs 1st and 2nd trimester) has any effect on mortality. } \\
\text { The results do not show enough evidence of } \\
\text { differences across these groups. }\end{array}$ & None \\
\hline
\end{tabular}




\begin{tabular}{|c|c|c|c|c|}
\hline $\begin{array}{l}\text { Havari and } \\
\text { Peracchi } \\
\text { (2017) Europe }\end{array}$ & $\begin{array}{l}\text { Outcomes: Self-reported health, } \\
\text { chronic conditions, } \\
\text { mental health problems } \\
\text { Exposure: Exposure to war, } \\
\text { hunger, and parent absence } \\
\text { during childhood }\end{array}$ & $\begin{array}{l}\text { Variation in birth } \\
\text { cohorts born during } \\
\text { WWI }\end{array}$ & $\begin{array}{l}\text { The authors find that exposure to war and hunger are } \\
\text { associated with worse health ( } 3-7 \mathrm{p} \cdot \mathrm{p} \text {. decrease in } \\
\text { likelihood of good self-reported health). }\end{array}$ & $\begin{array}{l}\text { War matters more } \\
\text { for females, } \\
\text { whereas hunger } \\
\text { more for males. }\end{array}$ \\
\hline $\begin{array}{l}\text { Kesternich et al } \\
(2015) \\
\text { Germany }\end{array}$ & $\begin{array}{l}\text { Outcomes: Obesity in adulthood } \\
\text { Exposure: Hunger episodes } \\
\text { during childhood. }\end{array}$ & $\begin{array}{l}\text { Food supply (calories } \\
\text { per capita per month) } \\
\text { varied over time and } \\
\text { occupation zone, as } \\
\text { additional to hunger } \\
\text { recall. }\end{array}$ & $\begin{array}{l}\text { The authors find the treated individuals more likely to } \\
\text { spent a higher share of their income on food, leading to } \\
\text { a 3-6p.p. increase in the likelihood of obesity. }\end{array}$ & $\begin{array}{l}\text { The effect on } \\
\text { likelihood of } \\
\text { obesity is larger } \\
\text { for individuals in } \\
\text { low income } \\
\text { households. } \\
\text { Moreover, the } \\
\text { effect on food } \\
\text { spending share is } \\
\text { also larger for low } \\
\text { income } \\
\text { individuals. }\end{array}$ \\
\hline
\end{tabular}




\begin{tabular}{|c|c|c|c|c|}
\hline $\begin{array}{l}\text { Kesternich et al } \\
\text { (2014) Europe }\end{array}$ & $\begin{array}{l}\text { Outcomes: Diabetes, heart } \\
\text { disease, height, depression and } \\
\text { self-reported health } \\
\text { Exposure: Living during WWII } \\
\text { and living in a region that } \\
\text { experienced war combat during } \\
\text { childhood }\end{array}$ & $\begin{array}{l}\text { Timing and location of } \\
\text { WWII controlling for } \\
\text { country and birth year }\end{array}$ & $\begin{array}{l}\text { The authors find significant effects for diabetes ( } 3 \text { p.p.), } \\
\text { depression (6p.p.) and self-reported health (9p.p.), but } \\
\text { not for heart disease and height. Moreover, they } \\
\text { identify the following channels of war: hunger, } \\
\text { dispossession, persecution, father absence and } \\
\text { childhood immunisations. }\end{array}$ & $\begin{array}{l}\text { The negative } \\
\text { health effects do } \\
\text { not vary by } \\
\text { childhood SES } \\
\text { (however, } \\
\text { selfreported health } \\
\text { effects } \\
\text { concentrated on } \\
\text { middle class, and } \\
\text { heart disease } \\
\text { effects } \\
\text { concentrated in } \\
\text { the middle and } \\
\text { lower class). }\end{array}$ \\
\hline
\end{tabular}




\begin{tabular}{|c|c|c|c|c|}
\hline $\begin{array}{l}\text { Lehmann and } \\
\text { Wadsworth } \\
\text { (2011) } \\
\text { Ukraine }\end{array}$ & $\begin{array}{l}\text { Outcomes: self-reported health, } \\
\text { height, BMI, smoking, } \\
\text { drinking, anemia, gastro- } \\
\text { intestinal illness, heart disease } \\
\text { at } 23-59 \text { years old; } \\
\text { Exposure: radioactive fallout. }\end{array}$ & $\begin{array}{l}\text { Regional variation in } \\
\text { exposure due to } 1986 \\
\text { Chernobyl accident }\end{array}$ & $\begin{array}{l}\text { The authors find those exposed are more likely to be in } \\
\text { poor health (by } 13 \text { p.p.), more likely to suffer from } \\
\text { anaemia or gastro-intestional illness, but not more } \\
\text { likely to be underweight or obese, to drink or smoke, } \\
\text { all } 20 \text { years after,. }\end{array}$ & None \\
\hline $\begin{array}{l}\text { Lindeboom et } \\
\text { al (2010) } \\
\text { Netherlands }\end{array}$ & $\begin{array}{l}\text { Outcomes: Adult mortality } \\
\text { Exposure: Malnutrition in utero } \\
\text { or first month of life }\end{array}$ & $\begin{array}{l}\text { Exposure to Dutch } \\
\text { Potato famine } \\
1846 / 47 \text {. }\end{array}$ & $\begin{array}{l}\text { The authors find a negative effect ( } 4 \text { years for boys and } \\
2.5 \text { years for girls) of the famine early in life on } \\
\text { mortality after age } 50 \text {. Moreover, they find that higher } \\
\text { food prices at birth reduce this effect for children of } \\
\text { farmers, suggesting a positive income effect. }\end{array}$ & $\begin{array}{l}\text { The effect is } \\
\text { stronger for those } \\
\text { in lower social } \\
\text { class. Moreover, } \\
\text { men are affected } \\
\text { more than women. }\end{array}$ \\
\hline $\begin{array}{l}\text { Persson and } \\
\text { Rossin-Slater } \\
\text { (2018) Sweden }\end{array}$ & $\begin{array}{l}\text { Outcomes: Anti-anxiety and } \\
\text { depression medications } \\
\text { Exposure: Maternal stress during } \\
\text { pregnancy. }\end{array}$ & $\begin{array}{l}\text { Variation in timing of } \\
\text { death of family } \\
\text { member }\end{array}$ & $\begin{array}{l}\text { Exposure to the maternal stress caused by a relative's } \\
\text { death when in utero increases the use of medication for } \\
\text { anxiety and depression around age } 35 \text { ( } 813 \text { percent } \\
\text { increase in likelihood of using, and } 12-19 \text { percent } \\
\text { increase in daily use), when comparing with those } \\
\text { experiencing the death right after birth, to control for } \\
\text { income shocks. }\end{array}$ & $\begin{array}{l}\text { Effects do not } \\
\text { vary by maternal } \\
\text { education. }\end{array}$ \\
\hline $\begin{array}{l}\text { Portrait et al } \\
\text { (2017) } \\
\text { Netherlands }\end{array}$ & $\begin{array}{l}\text { Outcomes: Adult height } \\
\text { Exposure: Childhood } \\
\text { undernutrition }\end{array}$ & $\begin{array}{l}\text { Famine during } \\
\text { pregnancy due to Dutch } \\
\text { Hunger Winter } \\
\text { 1944/45. Variation in } \\
\text { the moment and place } \\
\text { of birth. }\end{array}$ & $\begin{array}{l}\text { The authors examine the famine effects at various ages } \\
\text { using the unaffected areas as control group. They find } \\
\text { significant effects (about } 4-4.5 \mathrm{~cm} \text { ) of experiencing the } \\
\text { famine for ages under } 2 \text {, but no significant effects for } \\
\text { any other age group until } 15 \text { years old. }\end{array}$ & $\begin{array}{l}\text { Effect is stronger } \\
\text { for girls than for } \\
\text { the boys, when } \\
\text { looking at } \\
\text { exposure under } \\
\text { age } 1 \text { (when } \\
\text { exposure under } \\
\text { age } 2 \text { effects are } \\
\text { same for both } \\
\text { males and } \\
\text { females). }\end{array}$ \\
\hline
\end{tabular}




\begin{tabular}{|c|c|c|c|c|}
\hline $\begin{array}{l}\text { Schiman et al } \\
(2017) \\
\text { England and } \\
\text { Wales }\end{array}$ & $\begin{array}{l}\text { Outcomes: Self-reported health, } \\
\quad \text { incidence of health } \\
\text { problems, disability status at age } \\
40 \text { to } 73 \\
\text { Exposure: Infant during } \\
\text { WWII }\end{array}$ & $\begin{array}{l}\text { Variation in region and } \\
\text { cohort being infant } \\
\text { during WWI }\end{array}$ & $\begin{array}{l}\text { The authors exploit variation in infant mortality } \\
\text { caused by food rationing and harsh conditions during } \\
\text { WWII and find its strong association with later in life } \\
\text { disability ( } 1 \text { s.d. increase in infant mortality associated } \\
\text { with } 39 \% \text { increase in disability). In particular, the effect } \\
\text { was stronger later in life (above age } 60 \text { ). However, the } \\
\text { effects on self-reported health and incidence of health } \\
\text { problems were not significant. }\end{array}$ & $\begin{array}{l}\text { No heterogeneous } \\
\text { effects found for } \\
\text { SES. }\end{array}$ \\
\hline $\begin{array}{l}\text { Scholte et al } \\
(2015) \\
\text { Netherlands }\end{array}$ & $\begin{array}{l}\text { Outcomes: Hospitalisation later } \\
\text { in life } \\
\text { Exposure: Malnutrition during } \\
\text { pregnancy. }\end{array}$ & $\begin{array}{l}\text { Famine during } \\
\text { pregnancy due to Dutch } \\
\text { Hunger Winter } \\
\text { 1944/45. Variation in } \\
\text { the moment and place } \\
\text { of birth. }\end{array}$ & $\begin{array}{l}\text { The authors find exposure to the Dutch Hunger Winter } \\
\text { to have higher hospitalisation rates }(2 \%-7 \%) \text { in the } \\
\text { years before retirement if exposure occurred in middle } \\
\text { or late gestation stage. }\end{array}$ & $\begin{array}{l}\text { The effects are } \\
\text { stronger for males, } \\
\text { than for women. }\end{array}$ \\
\hline $\begin{array}{l}\text { Scholte et al } \\
(2017) \\
\text { Netherlands }\end{array}$ & $\begin{array}{l}\text { Outcomes: Physical functional } \\
\text { limitations in daily-life } \\
\text { activities } \\
\text { Exposure: Economic conditions } \\
\text { early in life. }\end{array}$ & $\begin{array}{l}\text { Business cycle around } \\
\text { birth }\end{array}$ & $\begin{array}{l}\text { Those born during a recession are more volatile to } \\
\text { adverse life events, such as chronic diseases, as the } \\
\text { impact ( } 0.09 \text { effect on number of difficulties) on } \\
\text { function limitation in later life is much higher (an } \\
\text { additional 0.11) for those who experienced such } \\
\text { adverse early-life condition. }\end{array}$ & $\begin{array}{l}\text { The effects are } \\
\text { stronger for males } \\
\text { for chronic } \\
\text { diseases, but not } \\
\text { for any other } \\
\text { adverse life event. }\end{array}$ \\
\hline $\begin{array}{l}\text { Van den Berg et } \\
\text { al (2016) } \\
\text { Germany, } \\
\text { Netherlands, } \\
\text { Greece }\end{array}$ & $\begin{array}{l}\text { Outcomes: Adult height } \\
\text { Exposure: Malnutrition } \\
\text { Nutritional shortage due to } \\
\text { famine in childhood }(0-16)\end{array}$ & $\begin{array}{l}\text { IV using self-reported } \\
\text { hunger episodes and } \\
\text { variation in birth } \\
\text { cohorts exposed to } \\
\text { famine }\end{array}$ & $\begin{array}{l}\text { The authors instrument retrospective reporting of } \\
\text { hunger episodes during childhood using the exposure } \\
\text { to the famines induced by WWII. }\end{array}$ & $\begin{array}{l}\text { For males a } \\
\text { negative effect of } \\
3 \mathrm{~cm} \text { on adult } \\
\text { height for } \\
\text { undernutrition } \\
\text { between in utero } \\
\text { and age } 4 \text {, but no } \\
\text { significant effect } \\
\text { for females. }\end{array}$ \\
\hline
\end{tabular}




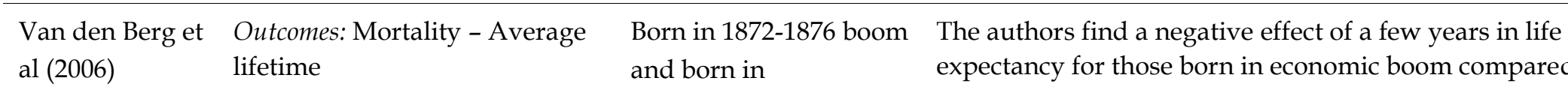

Netherlands
1877-1881 recession to those born in recession.
Adverse economic

conditions at birth

affect more men

than women,

while parents

social class effect

is stronger for

women.

\section{Wernerfelt al (2017) USA \\ et Outcomes: Incidence of asthma in adulthood Exposure: Sunlight exposure in utero.}

\section{Variation in sunlight} within-location across counties (and time use data for spending more time outdoors when there is more sunlight)
The authors examine the link between maternal vitamin D levels during pregnancy and likelihood of asthma for the offspring. They achieve this by using variation in sunlight (a source of vitamin D) and find significant effect for sunlight during the second trimester (a double amount of sunshine is associated with 1p.p. decrease in probability of asthma), which highlights the critical period of the second trimester of pregnancy.

\begin{tabular}{ll}
\hline $\begin{array}{l}\text { Yemelyanau et } \\
\text { al (2012) Be- }\end{array}$ & $\begin{array}{l}\text { Outcomes: medical visits, being } \\
\text { hospitalized, self-reported } \\
\text { being in good health (up to age } \\
\text { larus }\end{array}$ \\
& $\begin{array}{l}\text { Exposure: radioactive fallout in } \\
\text { early childhood (age 1-16) }\end{array}$
\end{tabular}

\section{Regional and age} variation in exposure due to 1986 Chernobyl accident
The authors find that individuals exposed in the most contaminated areas to have more medical visits (by about 1 visit), less likely to be in good health (by 7 p.p.), though radiation exposure has no effect on the probability of hospitalisation. The effects are stronger for younger individuals in the more contaminated.
None

Effect on medical visits significant only for men (and only for the most affected areas) while effect on self-reported health significant and same for both men and women. 
Table A2: Summary of papers discussed in the main text - Interventions

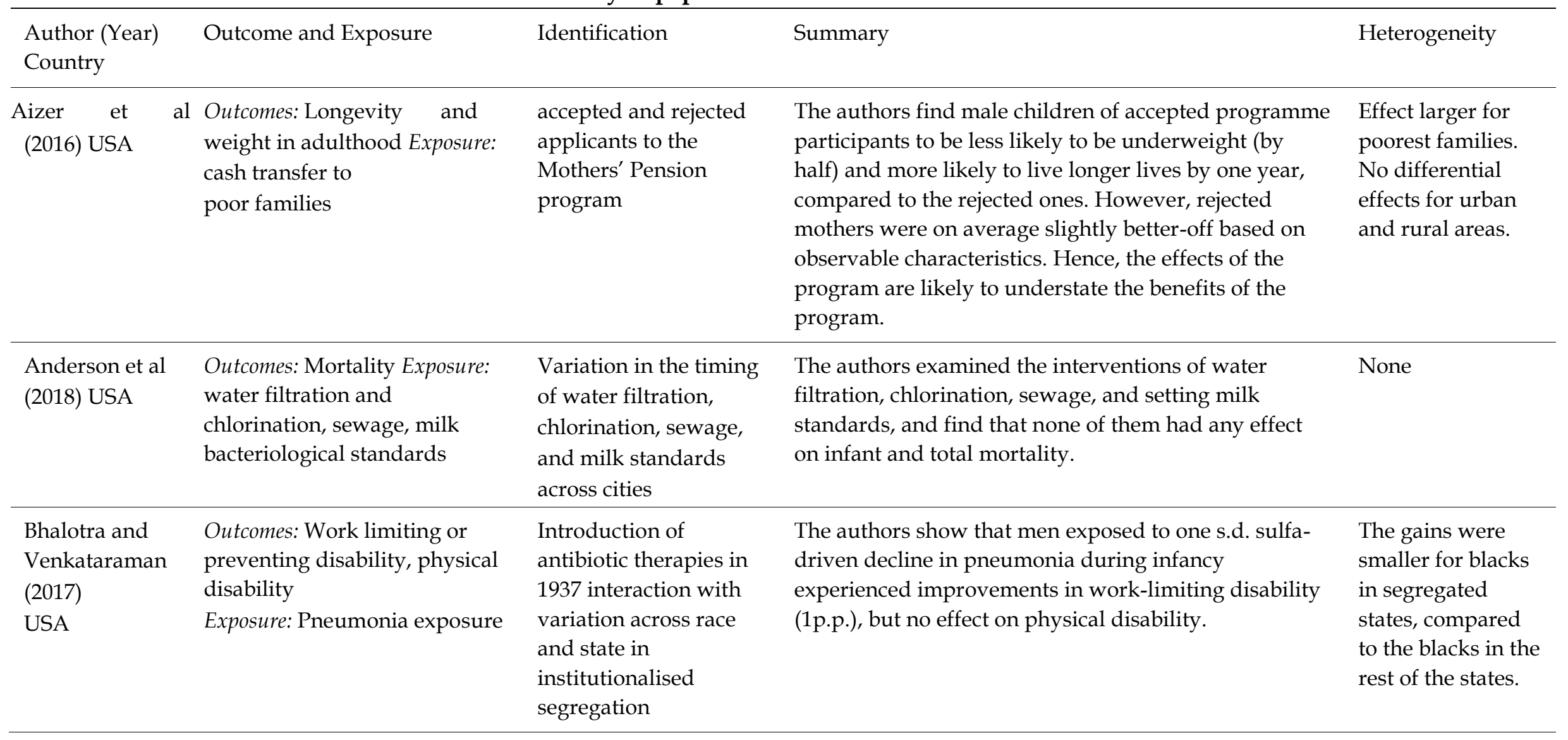




\begin{tabular}{|c|c|c|c|c|}
\hline $\begin{array}{l}\text { Bhalotra et al } \\
\text { (2017) Sweden }\end{array}$ & $\begin{array}{l}\text { Outcomes: Mortality - death by } \\
\text { age } 75 \text {, and death by age } 50 \\
\text { Exposure: Infant care } \\
\text { programmes - mother support } \\
\text { (nutrition and sanitation) and } \\
\text { infant care (home visits and } \\
\text { clinics) during infancy }\end{array}$ & $\begin{array}{l}\text { Variation in time and } \\
\text { medical districts }\end{array}$ & $\begin{array}{l}\text { The intervention had short- (1.5p.p.) and long-term } \\
\text { (2.5p.p.) effects on mortality, especially for mortality } \\
\text { caused by cancer and cardiovascular diseases. }\end{array}$ & $\begin{array}{l}\text { The effects were } \\
\text { stronger for } \\
\text { children born } \\
\text { outside marriage, } \\
\text { and some } \\
\text { evidence that also } \\
\text { stronger for } \\
\text { younger mothers. } \\
\text { No heterogeneous } \\
\text { effects by gender } \\
\text { or local economic } \\
\text { conditions. }\end{array}$ \\
\hline
\end{tabular}

Boudreaux et al Outcomes: Self-reported health,

(2016) USA blood pressure, heart disease,

diabetes, obesity (age 25-34)

$\stackrel{\infty}{\infty}$

\section{Variation in}

implementation across

the states in

combination with

individual-level

variation in probability

to participate
The authors find no significant effect on selfreported

health. Regarding the other outcomes, they construct a

chronic condition index from these 4 outcomes and

find a significant effect on this index (from no to full

exposure 0.35 s.d. decrease). However, examining each

outcome separate, the effect is concentrated on high

blood pressure. The effect becomes much larger (3.5

s.d.) when interacted with predicted participation

probability merged using Census information based on state, age and race.

$\begin{array}{lll}\text { Brown et al } & \text { Outcomes: Mortality at age 28 } & \text { Variation in } \\ \text { (2015) USA } & \begin{array}{l}\text { Exposure: Medicaid in childhood } \\ \text { (age 0-18) }\end{array} & \begin{array}{l}\text { implementation across } \\ \text { the states in }\end{array} \\ & & \text { combination with } \\ & & \text { individual-level } \\ & & \text { variation in probability } \\ & \text { to participate }\end{array}$

The authors find a decrease in mortality through the age 28 , conditional on survived at age 18 . While the effect of one s.d. increase in Medicaid eligibility on females is smaller and not significant at $28(3 \%)$, but larger at 26 and $27(11 \%)$, the effect for males in larger and more robust $(5 \%)$ across all ages. This is probably because male mortality is, in general, higher at these
The effect for men is greater, and more robust, than for women. 


\begin{tabular}{|c|c|c|c|c|}
\hline $\begin{array}{l}\text { Bu“tikofer et al } \\
\text { (2015) Norway }\end{array}$ & $\begin{array}{l}\text { Outcomes: BMI, Likelihood of } \\
\text { obesity, blood pressure, } \\
\text { hypertension, cardiac risk, } \\
\text { cholesterol risk, height at age } \\
40 \\
\text { Exposure: Child health care } \\
\text { centres aiming at information } \\
\text { on infant nutrition }\end{array}$ & $\begin{array}{l}\text { DiD of implementation } \\
\text { across municipalities } \\
\text { and time }\end{array}$ & $\begin{array}{l}\text { The authors find treated individuals experience a } \\
\text { reduction in BMI ( } 0.3 \text { points), likelihood of obesity } \\
(2 \text { p.p.), blood pressure }(1 \mathrm{~mm}) \text {, hypertension (1p.p.), } \\
\text { cholesterol risk ( } 3 \text { p.p.), and a combined index for bad } \\
\text { health }(0.24 \text { s.d.). Effects on the separate outcomes } \\
\text { were significant only for men, whereas the effect on } \\
\text { index was significant for both. In addition, they show } \\
\text { that better nutrition in early-life has positive effects on } \\
\text { height }(2 \mathrm{~cm}) \text { at age } 40 \text { for both. }\end{array}$ & $\begin{array}{l}\text { Effects are } \\
\text { stronger (and } \\
\text { significant) for } \\
\text { men than women. }\end{array}$ \\
\hline $\begin{array}{l}\text { Bütikofer } \\
\text { and Salvanes } \\
\text { (2018) Norway }\end{array}$ & $\begin{array}{l}\text { Outcomes: Adult height (men } \\
\text { only) and mortality (dying } \\
\text { before age } 66 \text { ) } \\
\text { Exposure: Tuberculosis testing } \\
\text { and vaccination program } \\
\text { while at school }\end{array}$ & $\begin{array}{l}\text { Cohort (1948 launch) } \\
\text { and regional (infection } \\
\text { rates) variation }\end{array}$ & $\begin{array}{l}\text { The authors find that cohorts that were in school } \\
\text { during and after the implementation in areas with } \\
\text { higher tuberculosis rates gained more longevity as the } \\
\text { likelihood of dying before age } 66 \text { decreased by } 1 \mathrm{p} . \mathrm{p} . . \\
\text { The effect on mens' adult height was a } 1.5 \mathrm{~cm} \text { increase. }\end{array}$ & $\begin{array}{l}\text { The effects on } \\
\text { mortality are } \\
\text { concentrated in } \\
\text { women. }\end{array}$ \\
\hline $\begin{array}{l}\text { Campbell et al } \\
\text { (2014) USA }\end{array}$ & $\begin{array}{l}\text { Outcomes: Cardiovascular and } \\
\text { metabolic diseases in mid-30s; } \\
\text { health care utilisation at age } 30 \\
\text { and obesity } \\
\text { Exposure: Carolina Abecedarian } \\
\text { Project (ABC) stimulating early } \\
\text { childhood environment }\end{array}$ & $\mathrm{RCT}$ & $\begin{array}{l}\text { The authors find that disadvantaged children } \\
\text { randomly exposed to the treatment (ABC intervention) } \\
\text { have significantly lower prevalence of risk factors for } \\
\text { cardiovascular and metabolic diseases in their mid 30s } \\
\text { (diastolic bp: } 13.5 \mathrm{~mm} \text { and systolic bp: } 17.5 \mathrm{~mm} \text {, } \\
\text { hypertension: } 33 \mathrm{p} . \mathrm{p} \text {. and vitamin D deficiency } 38 \mathrm{p} . \mathrm{p} \text {. } \\
\text { for males; abdominal obesity } 20 \mathrm{p} . \mathrm{p} \text {. for women). In } \\
\text { addition, treated males are found more likely to have } \\
\text { health insurance at age } 30 \\
\text { (23p.p.). }\end{array}$ & $\begin{array}{l}\text { The effects are } \\
\text { stronger for men } \\
\text { than for women. }\end{array}$ \\
\hline
\end{tabular}




\begin{tabular}{|c|c|c|c|c|}
\hline $\begin{array}{l}\text { Carneiro and } \\
\text { Ginja (2014) } \\
\text { USA }\end{array}$ & $\begin{array}{l}\text { Outcomes: Self-reported health } \\
\text { and overweight at age } 20-21 \\
\text { Exposure: Preschool program } \\
\text { Head Start }\end{array}$ & $\begin{array}{l}\text { Fuzzy RDD around } \\
\text { income eligibility } \\
\text { cutoff (multiple points) } \\
\text { and IV regression for } \\
\text { eligibility }\end{array}$ & $\begin{array}{l}\text { The authors examine the medium-term effects of the } \\
\text { Head Start, a preschool program targeting at } \\
\text { disadvantaged children in the US. Although they find } \\
\text { some effects for chronic conditions and obesity at ages } \\
\text { 12-13, and for depression and obesity at ages } 16-17 \text {, at } \\
\text { ages } 20-21 \text { there is no significant effect for any health } \\
\text { outcome. }\end{array}$ & $\begin{array}{l}\text { The authors } \\
\text { attempt to } \\
\text { estimate } \\
\text { heterogeneous } \\
\text { effects, but they } \\
\text { report them as } \\
\text { imprecise. }\end{array}$ \\
\hline $\begin{array}{l}\text { Conti et al } \\
\text { (2016) USA }\end{array}$ & $\begin{array}{l}\text { Outcomes: height, weight, } \\
\text { obesity, blood pressure, } \\
\text { hypertension, hospitalisation } \\
\text { Exposure: Perry Preschool Project } \\
\text { and Carolina Abecedarian } \\
\text { Project - early childhood }\end{array}$ & $\mathrm{RCT}$ & $\begin{array}{l}\text { The authors find the treated males to have lower BMI } \\
\text { ( } 4 \text { points), to be lighter }(7 \mathrm{~kg}) \text { and taller }(5 \mathrm{~cm}) \text {, to have } \\
\text { lower values of systolic and diastolic blood pressure } \\
\text { ( } 13.5 \mathrm{~mm} \text { and } 17.5 \mathrm{~mm}) \text {, less likely to fall into the Stage I } \\
\text { hypertension category ( } 34 \text { p.p.) or to be hospitalised } \\
\text { (35p.p.) than the control. }\end{array}$ & $\begin{array}{l}\text { The effects are } \\
\text { stronger for men } \\
\text { than for women. }\end{array}$ \\
\hline $\begin{array}{l}\text { Cutler } \quad \text { and } \\
\text { Miller } \\
\text { USA }\end{array}$ & $\begin{array}{l}\text { Outcomes: Adult mortality } \\
\text { Exposure: filtration and } \\
\text { chlorination }\end{array}$ & $\begin{array}{l}\text { Diff-in-Diff exploiting } \\
\text { variation in the timing } \\
\text { of water filtration and } \\
\text { chlorination across } \\
\text { cities }\end{array}$ & $\begin{array}{l}\text { Clean water access decreased by almost half the } \\
\text { mortality rates in major cities, by } 75 \% \text { infant mortality } \\
\text { and by two third child mortality rates. Their analysis } \\
\text { suggests that these public health interventions acted as } \\
\text { complements. In a cost-benefit analysis they predict } \\
\text { that the return rate to clean water technologies was } \\
\text { about } 23 \text { to } 1 \text { and that the cost per person-year saved } \\
\text { was about } 500 \text { USD (2003). }\end{array}$ & $\begin{array}{l}\text { The impact was } \\
\text { larger for cities } \\
\text { with higher } \\
\text { illiteracy rate. }\end{array}$ \\
\hline $\begin{array}{l}\text { Goodman-Bacon } \\
(2016) \\
\text { USA }\end{array}$ & $\begin{array}{l}\text { Outcomes: Mortality and } \\
\text { disability (hearing, vision, } \\
\text { mobility, self-care, work } \\
\text { limitation) in adulthood up to } \\
\text { 60s. Exposure: Medicaid in } \\
\text { childhood (age } 0-18 \text { ) }\end{array}$ & $\begin{array}{l}\text { DiD and cohort } \\
\text { eligibility IV }\end{array}$ & $\begin{array}{l}\text { This study provides an assessment of the Medicaid } \\
\text { using its original introduction, thus enabling the study } \\
\text { of long-term effects for the participants up to their 60s. } \\
\text { The author finds strong effects for mortality and } \\
\text { disability (both about } 20 \% \text { ). Moreover, younger age } \\
\text { eligibility is associated with higher gains. In addition, } \\
\text { the author provides an estimate for government } \\
\text { savings of 3-11 percent of the programme's cost }\end{array}$ & $\begin{array}{l}\text { White children } \\
\text { have larger gains } \\
\text { compared to } \\
\text { nonwhite children. }\end{array}$ \\
\hline
\end{tabular}




\begin{tabular}{|c|c|c|c|c|}
\hline $\begin{array}{l}\text { Gould et al } \\
\text { (2011) Israel }\end{array}$ & $\begin{array}{l}\text { Outcomes: Self-reported health } \\
\text { problems, disability income } \\
\text { support at ages around 50-60 } \\
\text { Exposure: Moving to a more } \\
\text { modern environment in } \\
\text { childhood }\end{array}$ & $\begin{array}{l}\text { Quasi-random } \\
\text { allocation of Jewish } \\
\text { Yemenite immigrant } \\
\text { families in Israel, after } \\
\text { airlift rescue operation } \\
\text { in } 1949\end{array}$ & $\begin{array}{l}\text { The authors found no effect of the quality of the early } \\
\text { childhood environment on late adulthood health } \\
\text { outcomes. }\end{array}$ & None \\
\hline $\begin{array}{l}\text { Herbst }(2 \\
\text { USA }\end{array}$ & $\begin{array}{l}\text { Outcomes: Work-related dis- } \\
\text { ability } \\
\text { Exposure: Universal child care for } \\
\text { children at ages } 0-12\end{array}$ & $\begin{array}{l}\text { Diff-in-Diff using } \\
\text { variation in eligible age } \\
\text { participation and } \\
\text { variation across states } \\
\text { on spending intensity } \\
\text { on preschool program }\end{array}$ & $\begin{array}{l}\text { The program resulted in preschool centres (for children } \\
\text { 0-5) and after-school services (for children 612) } \\
\text { through the Lanham Act } 1940 \text { due to WWII. The } \\
\text { treated cohorts are those born } 1931-1946 \text { and the } \\
\text { control 1947-1951, along with the interaction of the } \\
\text { program spending. The author finds that for a 100USD } \\
\text { increase in spending, there is a } 0.3 \text { p.p. decrease in the } \\
\text { probability of work-related disability at ages } 24-39 \text {. }\end{array}$ & None \\
\hline $\begin{array}{l}\text { Hjort et al } \\
(2017) \text { Den- } \\
\text { mark }\end{array}$ & $\begin{array}{l}\text { Outcomes: Mortality, hospital } \\
\text { nights and cardiovascular } \\
\text { disease } \\
\text { Exposure: } 1937 \text { Danish home } \\
\text { visiting program }\end{array}$ & $\begin{array}{l}\text { DiD using variation } \\
\text { across municipalities } \\
\text { implementing the } \\
\text { program born 1935- } \\
1949\end{array}$ & $\begin{array}{l}\text { Treated individuals are } 5-8 \text { percent less likely to die } \\
\text { middle aged (45-57), less likely to be diagnosed with or } \\
\text { die from cardiovascular diseases, and spend about half } \\
\text { night less in hospital. }\end{array}$ & $\begin{array}{l}\text { Effects on } \\
\text { mortality similar } \\
\text { for men and } \\
\text { women. }\end{array}$ \\
\hline
\end{tabular}




\begin{tabular}{|c|c|c|c|c|}
\hline $\begin{array}{l}\text { Hoynes et al } \\
\text { (2016) USA }\end{array}$ & $\begin{array}{l}\text { Outcomes: Obesity, high blood } \\
\text { pressure, heart disease, } \\
\text { diabetes, general health status, } \\
\text { disability } \\
\text { Exposure: Share of time } \\
\text { between conception and age } \\
\text { five that a food stamp program } \\
\text { was available }\end{array}$ & $\begin{array}{l}\text { DiD over county and } \\
\text { cohort of birth. Also } \\
\text { DiDiD using variation } \\
\text { across subgroups with } \\
\text { varying propensities to } \\
\text { use the program }\end{array}$ & $\begin{array}{l}\text { The authors find treated individuals (defined as those } \\
\text { who have additional exposure to the Food Stamp } \\
\text { Programme earlier in childhood, compared to having it } \\
\text { later in childhood) more likely to have a reduction in } \\
\text { the incidence of 'metabolic syndrome', constructed } \\
\text { from obesity, high blood pressure, heart disease/attach } \\
\text { and diabetes ( } 0.3 \text { s.d. reduction for full participation } \\
\text { compared to none) and more likely to report they are } \\
\text { in good health (11p.p.). Access to the programme is } \\
\text { also found to decrease stunting for treated individuals. } \\
\text { The effect on work-limited disability is in the expected } \\
\text { direction (i.e. an improvement arosen from access to } \\
\text { the programme), though its effect is statistically } \\
\text { insignificant. }\end{array}$ & $\begin{array}{l}\text { The effect on } \\
\text { metabolic } \\
\text { syndrome is } \\
\text { larger for males } \\
\text { than for females, } \\
\text { however the } \\
\text { opposite was } \\
\text { found for } \\
\text { self-reported } \\
\text { health. }\end{array}$ \\
\hline $\begin{array}{l}\text { Kesztenbaum } \\
\text { and Rosenthal } \\
\text { (2017) France }\end{array}$ & $\begin{array}{l}\text { Outcomes: Total Mortality } \\
\text { (Life expectancy at age 1) } \\
\text { Exposure: Sanitation }\end{array}$ & $\begin{array}{l}\text { Diff-in-Diff using time } \\
\text { and neighbourhood } \\
\text { fixed effects }\end{array}$ & $\begin{array}{l}\text { The authors find that sanitation increased the } \\
\text { lifeexpectancy of Parisians by } 2 \text { years. }\end{array}$ & $\begin{array}{l}\text { The gains are } \\
\text { similar for men } \\
\text { and women. }\end{array}$ \\
\hline $\begin{array}{l}\text { Ludwig et al } \\
(2013 b) \text { USA }\end{array}$ & $\begin{array}{l}\text { Outcomes: Self-rated health, } \\
\text { sleeping hours, mobility } \\
\text { troubles, asthma, hypertension, } \\
\text { obesity, diabetes and } \\
\text { psychological distress, calm } \\
\text { and peaceful } \\
\text { Exposure: Moving to a less- } \\
\text { disadvantaged neighbourhood } \\
\text { in childhood }\end{array}$ & $\begin{array}{l}\text { RCT Moving to } \\
\text { Opportunity (MTO) } \\
\text { randomised housing } \\
\text { mobility experiment }\end{array}$ & $\begin{array}{l}\text { The authors find that a move to a better } \\
\text { neighbourhood, as a result from from the } \\
\text { randomisation, reduces the likelihood of adult physical } \\
\text { health and mental health problems (both standardised } \\
\text { indices constructed using the surveyed outcomes) } 1015 \\
\text { years later. }\end{array}$ & $\begin{array}{l}\text { Effects significant } \\
\text { only for girls. }\end{array}$ \\
\hline
\end{tabular}




\begin{tabular}{|c|c|c|c|c|}
\hline $\begin{array}{l}\text { Lu“hrmann and } \\
\text { Wilson (2018) } \\
\text { UK }\end{array}$ & $\begin{array}{l}\text { Outcomes: Mortality, } \\
\text { selfreported and } \\
\text { hospitalisations due to } \\
\text { cardiovascular disease at ages } \\
50-60 \\
\text { Exposure: access to healthcare } \\
\text { through NHS }\end{array}$ & $\begin{array}{l}\text { RDD around date of } \\
\text { introduction of NHS } \\
\text { (July 1948) }\end{array}$ & $\begin{array}{l}\text { The authors find significant effects of the introduction } \\
\text { of NHS at birth on mortality ( } 12 \% \text { decrease) at age } 57 \\
\text { and a significant decrease }(7 \%) \text { in the likelihood of } \\
\text { cardiovascular diseases among those from lower class } \\
\text { at their } 50 \text { s. In addition, they also find immediate } \\
\text { effects (decrease } 17 \% \text { on infant mortality). }\end{array}$ & $\begin{array}{l}\text { Mortality gains are } \\
\text { larger for lower } \\
\text { class individuals, } \\
\text { however there is } \\
\text { no differential } \\
\text { effects for } \\
\text { cardiovascular } \\
\text { diseases. }\end{array}$ \\
\hline $\begin{array}{l}\text { Miller and } \\
\text { Wherry (2018) } \\
\text { USA }\end{array}$ & $\begin{array}{l}\text { Outcomes: Diabetes, high blood } \\
\text { pressure, obesity, heart disease, } \\
\text { self-reported health and } \\
\text { psychological distress, and } \\
\text { hospitalisations, up to mid-30s. } \\
\text { Exposure: Medicaid in utero } \\
\text { and infant (first year after } \\
\text { birth) }\end{array}$ & $\begin{array}{l}\text { Variation in state and } \\
\text { cohort-level in the } \\
\text { timing and generosity of } \\
\text { Medicaid expansions } \\
\text { (instrumental } \\
\text { variables) }\end{array}$ & $\begin{array}{l}\text { Using both individual survey and administrative } \\
\text { hospital data, the authors find that Medicaid prenatal } \\
\text { eligibility reduced the likelihood of all chronic } \\
\text { conditions, separately and combined in one index ( } 0.03 \\
\text { s.d. decrease for every 10p.p. increase in early life } \\
\text { eligibility), but there were no effects on self-reported } \\
\text { health and psychological distress. In addition, there } \\
\text { were lower hospital admissions related to diabetes and } \\
\text { obesity }(8-10 \%) \text {. }\end{array}$ & $\begin{array}{l}\text { The effects were } \\
\text { larger for black } \\
\text { cohorts than } \\
\text { whites. }\end{array}$ \\
\hline $\begin{array}{l}\text { Rossin-Slater } \\
\text { and Wu“st } \\
\text { (2016) Denmark }\end{array}$ & $\begin{array}{l}\text { Outcomes: Mortality - death by } \\
65 \text { (among others) } \\
\text { Exposure: Preschool childcare } \\
\text { and nurse home visiting } \\
\text { program }\end{array}$ & $\begin{array}{l}\text { Variation in } \\
\text { municipalities that } \\
\text { introduced CC before } \\
\text { or after HV }\end{array}$ & $\begin{array}{l}\text { The authors find lower mortality rates for treated } \\
\text { individuals through the age of } 65 \text { ( } 0.5 \mathrm{p} . \mathrm{p} .) \text {. For women, } \\
\text { their results suggest that preschool access lowers the } \\
\text { likelihood of heart disease diagnosis }(0.03 \mathrm{pp}) \text {, while for } \\
\text { men it reduces the cancer diagnosis }(0.04 \mathrm{pp}) \text {. } \\
\text { Moreover, additional access to the Nurse Home } \\
\text { Visiting programme reduces the positive effects of the } \\
\text { preschool programme for most of the studied } \\
\text { outcomes. }\end{array}$ & $\begin{array}{l}\text { The mortality } \\
\text { effects are larger } \\
\text { for women than } \\
\text { for men. }\end{array}$ \\
\hline
\end{tabular}




\begin{tabular}{|c|c|c|c|c|}
\hline $\begin{array}{l}\text { Thomson } \\
\text { (2017) USA }\end{array}$ & $\begin{array}{l}\text { Outcomes: Self-reported health, } \\
\text { health limitation, chronic } \\
\text { condition, asthma at ages } 18-21 \\
\text { Exposure: Medicaid or CHIP in } \\
\text { childhood (age } 0-18 \text { ) }\end{array}$ & IV using eligibility & $\begin{array}{l}\text { The author finds strong effects for all four outcomes } \\
\text { and a health index combining all together ( } 0.08 \text { s.d. for } \\
\text { one additional year of eligibility). Furthermore, the } \\
\text { gains are larger for those with eligibility at age } 0-5 \text {, } \\
\text { than for those at } 6-11 \text { or } 12-18 \text {. }\end{array}$ & None \\
\hline $\begin{array}{l}\text { Wherry and } \\
\text { Meyer (2016) } \\
\text { USA }\end{array}$ & $\begin{array}{l}\text { Outcomes: Disease-related } \\
\text { mortality at } 19-23 \text { years old } \\
\text { Exposure: Childhood Medicaid } \\
\text { eligibility and coverage at ages } \\
8 \text { to } 14\end{array}$ & $\begin{array}{l}\text { RDD around birth date } \\
\text { cutoff (Sept 30,1983) } \\
\text { that expand } \\
\text { eligibility }\end{array}$ & $\begin{array}{l}\text { Although the authors find that the Medicaid eligibility } \\
\text { resulted in a decline in mortality at ages 15-18 for black } \\
\text { cohorts (19\%), there was no effect of mortality } \\
\text { improvement at ages 19-23. For white children there } \\
\text { was no mortality improvement. }\end{array}$ & $\begin{array}{l}\text { Significant effects } \\
\text { for black children, } \\
\text { while no effects } \\
\text { for white. }\end{array}$ \\
\hline $\begin{array}{l}\text { Wherry et al } \\
\text { (2018) USA }\end{array}$ & $\begin{array}{l}\text { Outcomes: Hospitalisation and } \\
\text { emergency department } \\
\text { utilisation at age } 25 \\
\text { Exposure: Childhood Medicaid } \\
\text { eligibility and coverage at ages } \\
8 \text { to } 14\end{array}$ & $\begin{array}{l}\text { RDD around birth date } \\
\text { cutoff (Sept 30, 1983) } \\
\text { that expand } \\
\text { eligibility }\end{array}$ & $\begin{array}{l}\text { Medicaid eligibility is associated with a decrease in } \\
\text { hospitalisation ( } 7-15 \%) \text { and emergency department } \\
\text { visits (2-5\%) at age } 25 \text { for black cohorts (but not at } 15 \text {, } \\
\text { suggesting long-term effects). There were no effects for } \\
\text { whites. Finally, the authors calculate that the black } \\
\text { cohorts' lower utilisation at age } 25 \text {, offsets } 3 \text { to } 5 \\
\text { percent of the cost of expanding Medicaid for black } \\
\text { and non-black cohorts. This suggests that gains should } \\
\text { be even larger for later life. }\end{array}$ & $\begin{array}{l}\text { Significant effects } \\
\text { for black children, } \\
\text { while no effects } \\
\text { for white. }\end{array}$ \\
\hline
\end{tabular}


Table A3: Summary of papers discussed in the main text - Birth weight

\begin{tabular}{|c|c|c|c|c|}
\hline $\begin{array}{l}\text { Author (Year) } \\
\text { Country }\end{array}$ & Outcome and Exposure & Identification & Summary & Heterogeneity \\
\hline $\begin{array}{l}\text { Behram } \\
\text { Rosenzweig } \\
\text { (2004) USA }\end{array}$ & $\begin{array}{l}\text { Outcomes: adult physical } \\
\text { characteristics }\end{array}$ & $\begin{array}{l}\text { Exogeneous increase } \\
\text { in intrauterine nutrient } \\
\text { consumption, twin fixed } \\
\text { effects }\end{array}$ & $\begin{array}{l}\text { The authors find that increasing birth weight has no } \\
\text { effect on the child's obesity later in life. However, they } \\
\text { find that each additional } 1 \mathrm{lb} \text { increases adult height by } \\
\text { 0.6in. }\end{array}$ & None \\
\hline $\begin{array}{l}\text { Bharadwaji et } \\
\text { al (2018) } \\
\text { Sweden }\end{array}$ & $\begin{array}{l}\text { Outcomes: infant mortality, } \\
\text { APGAR (newborn physical } \\
\text { condition) score }\end{array}$ & $\begin{array}{l}\text { Sibling and twin pair } \\
\text { fixed effects }\end{array}$ & $\begin{array}{l}\text { Infant mortality is reduced by } 6 \text { deaths per } 1000 \text { births } \\
\text { for a } 10 \% \text { increase in birth weight, where the effect on } \\
\text { the APGAR score is also significant ( } 0.47 \text { points } \\
\text { increase). Moreover, the effect of birth weight on infant } \\
\text { mortality has been on decline over time (1920s to } \\
\text { 1950s). }\end{array}$ & $\begin{array}{l}\text { No consistent } \\
\text { evidence of } \\
\text { heterogeneity by } \\
\text { maternal age, } \\
\text { education, or } \\
\text { family } \\
\text { composition. }\end{array}$ \\
\hline $\begin{array}{ll}\text { Black } & \text { et al } \\
(2007) & \text { Jorway }\end{array}$ & $\begin{array}{l}\text { Outcomes: Infant mortality, } \\
\text { height, BMI, birth weight of } \\
\text { first offspring. }\end{array}$ & $\begin{array}{l}\text { Twin fixed effects, } \\
\text { year and month- } \\
\text { of birth dummies }\end{array}$ & $\begin{array}{l}\text { The authors differentiate their findings between short- } \\
\text { run and long-run effects of birth weight. They show } \\
\text { that a } 10 \% \text { increase in birth weight reduced infant } \\
\text { mortality by } 4 \text { deaths per } 1,000 \text { births (shortterm } \\
\text { outcome) and increases height by } 0.57 \mathrm{~cm} \text { and BMI by } \\
0.11 \text { (long-term outcome for men aged } 1820 \text { ). Among } \\
\text { the female twin subsample who have children, the } \\
\text { authors find that a } 10 \% \text { increase in the mother's birth } \\
\text { weight leads to a } 1.5 \% \text { increase in the birth of her first } \\
\text { child. }\end{array}$ & None \\
\hline
\end{tabular}




Currie and Outcomes: Self-reported health at Correlational study
Hyson (1999) age 23 and 33.

UK
Looking at the probability of self-reporting fair/poor health at age 23, the authors find a significant 6p.p. increase for low birth weight for middle class women. Regarding the health at age 33, they only find a significant effect (7p.p.) for middle-class men. For both ages, high-class women are less likely to report fair/poor health.
The low birth weight effect

becomes weaker (and insignificant) for high class women. But this is not the case for

men.

\begin{tabular}{lll}
\hline Currie and & Outcomes: Offspring's birth & $\begin{array}{l}\text { Grandmother fixed } \\
\text { effects. }\end{array}$
\end{tabular}

The authors find that if the mother had low birth weight, her child is 3.9 p.p. more likely to have low birth weight.

The effects
are
stronger for lower
SES mothers.
Also, the effects
are stronger for
blacks than for
whites.
None

Twin study with family and birth year fixed effects newborn physical condition measure) score below seven about 10 p.p. more likely to die within one year compared to those with score of ten. Using birth weight rather than Apgar score, the authors find a similar relationship (9p.p. for those born between 1,000-1,500 grams). Infant health (APGAR scores and low birth weight) has no effect on survival at age 17 or on physician utilization between ages 12-17. 


\begin{tabular}{|c|c|c|c|c|c|}
\hline $\begin{array}{l}\text { Royer } \\
\text { USA }\end{array}$ & (2009) & $\begin{array}{l}\text { Outcomes: Diabetes, } \\
\text { pregnancy complications, and } \\
\text { offspring birth weight. }\end{array}$ & Twin-pair fixed effects & $\begin{array}{l}\text { The authors find that a significant effect ( } 7 \text { gram for } \\
\text { every } 100 \text { gram in monther's birth weight) of birth } \\
\text { weight on child's birth weight, but not for gestational } \\
\text { length. Moreover, they find a significant effect on the } \\
\text { likelihood of pregnancy complications ( } 5 \mathrm{p} . \mathrm{p} \text {. increase } \\
\text { for every } 100 \text { gram), but no significant effects on } \\
\text { hypertension, diabetes, or anaemia. }\end{array}$ & None \\
\hline
\end{tabular}

